\title{
Policy Responsiveness in Developing Democracies: Evidence from Latin America
}

\author{
Daniel Rojas*
}

January 11, 2022

\begin{abstract}
The literature on government responsiveness to public preferences has tended to treat responsiveness as a unitary phenomenon, asking whether or to what degree governments respond. In this paper, I argue that government responsiveness is likely to be unevenly distributed geographically. First, government responsiveness is absent in places controlled by non-state actors. Second, responsiveness decreases with voters' abstention. I provide empirical support for my arguments using administrative data from over 1,000 municipalities and more than four million administrative records of a CCT program in Colombia. I also examine responsiveness at the country level. I show that, in Latin American countries where the electorate is at the left side of the government's ideological position, governments redistribute more. My findings on unequal responsiveness have implications for subnational socioeconomic inequalities.
\end{abstract}

Keywords: responsiveness, redistribution, Latin America, administrative data

Word count: 8780

${ }^{*}$ PhD Student, Department of Political Science, University of British Columbia. daniel.rojaslozano@ubc.ca 


\section{Introduction}

There is substantial evidence of government responsiveness in developing democracies (Golden and Min, 2013; Grossman and Slough, 2022). Existing scholarship shows that governments adjust their policies in response to electoral competition (Schady, 2000; Garay, 2016; Fairfield and Garay, 2017), citizens' needs (Besley and Burgess, 2002), public policy preferences (Roberts and Kim, 2011), political party alignment at the subnational level (Khemani, 2007; Brollo and Nannicini, 2012), or reelection motives (Gonschorek, Schulze and Sjahrir, 2018). Although these studies provide valuable insights into government responsiveness, they say little about the conditions under which we observe responsiveness. There are reasons to expect heterogeneous responsiveness within countries.

In developing democracies, states have an uneven capacity over the territory (Migdal, 1988; Scott, 1998; Herbst, 2000). Recent studies show that non-state actors provide socioeconomic order in places where the state is absent (Blattman et al., 2021; Peñaranda Currie, Otero-Bahamon and Uribe, 2021). I argue that in these contexts, non-state governance substitutes state governance and breaks the chain of policy responsiveness because it limits the government institutional capacity to respond to public preferences. Specifically, I posit that governments are unresponsive to citizens preferences in places where the state is absent and non-state actors provide socioeconomic order.

Likewise, there is heterogeneous voter turnout at the subnational level in developing democracies (Besley and Burgess, 2002; Lehoucq and Wall, 2004). Because elections are the mechanism that allows citizens to express their preferences, I argue that places with low voter turnout have citizens with weaker policy preferences and generate fewer incentives for governments to respond. In consequence, governments are less responsive to citizens in places with low voter turnout.

In this paper, I test for these two forms of heterogeneity by examining how governments adjust 
policy in response to citizens' preferences as expressed in election results. I rely on the ideological distinction between left and right to operationalize such preferences. As opposed to the right, the left has been historically associated with redistribution and social spending. I use municipal-level vote shares of left-wing candidates competing in national elections as a proxy of preference for redistribution. With these data, I build a measure of electorate distance from the central government. The electorate distance captures how far to the left the electorate is at the municipal level, compared to the central government ideological position. My measure of electorate distance is sensitive to ideological variation among left-wing candidates. Therefore, the vote share of a far-left candidate should lead to a higher response than the same vote share of a center-left candidate. I operationalize policy responsiveness as the additional proportion of government transfers a municipality receives. A particular feature of my analysis is that it distinguishes between nondiscretionary and discretionary transfers. The former is based on specific criteria; the latter is conditional on citizens' socioeconomic characteristics and budget availability.

I exploit sub-national variation in the preference for redistribution in Colombia to empirically test my hypotheses. Although data on preferences for redistribution is scant at the subnational level, I use elections data to measure redistributive preferences. In Colombia, people directly elect the president every four years. There is variety in the ideological positions of presidential candidates, and the long history of armed conflict makes the left-right distinction particularly salient. Additionally, the state has an uneven control over the territory, and abstention in presidential elections varies across municipalities. In the early 2000s, Colombia implemented nondiscretionary central government transfers to municipalities. Such transfers are redistributive by design. In addition, the Colombian government started Familias en Acción, a (discretionary) conditional cash transfer (CCT) program to alleviate poverty. I use data on the 2006, 2010, 2014, and 2018 presidential elections, 13 years of central government transfers from over 1,000 municipalities, and more 
than four million administrative records of a CCT program in Colombia to empirically test my arguments. To the best of my knowledge, no previous study has used these data.

I employ two-way fixed effects panel regression models and find that governments respond to public preferences for redistribution. Specifically, I find that municipalities, where the electorate is one standard deviation to the left of the government ideological position, receive around 2.8 percent higher nondiscretionary transfers per capita than municipalities where the electorate does not deviate from the government ideological position. Moreover, I find that the number of CCT beneficiaries in such municipalities increases by around 20 percent. However, I find heterogeneous effects: there is no responsiveness in municipalities historically controlled by non-state actors. Furthermore, the effect of the leftist support for redistribution decreases with voter abstention. I also examine responsiveness at the country level. I show that, in Latin American countries where the electorate is at the left side of the government ideological position, governments redistribute more.

My study makes important empirical and theoretical contributions to our understanding of policy responsiveness. A relevant empirical contribution is the fine-grained administrative data at the subnational level to measure policy preferences, responsiveness, and the mechanisms that condition it. Importantly, these data allow me to investigate responsiveness through nondiscretionary and discretionary transfers. Previous studies focus on discretionary transfers to assess responsiveness. I show that governments might also respond by using nondiscretionary transfers. This is important because it suggests that transfers are unlikely to be based only on technical criteria; nondiscretionary transfers can be adjusted by using the information provided by citizens' preferences.

Under which conditions does policy responsiveness hold? I make a relevant theoretical contribution by proposing that responsiveness varies by degree of state control and levels of citizen 
participation. This heterogeneous responsiveness has implications for subnational inequality in developing democracies. Specifically, it implies that low levels of state control and citizen participation can further exacerbate subnational socioeconomic disparities. In order to understand why some subnational units lag behind others, it is important to consider whether the conditions for governments to respond to citizens' preferences are present.

\section{Responsiveness}

Research on government responsiveness in developing democracies shows that governments adjust their policies in response to several factors. Studies that focus on the politics of redistribution emphasize how electoral competition led to the implementation or reform of social policies. For example, Schady (2000) shows that in Peru, former president Fujimori increased spending on a discretionary social fund in provinces where he had a larger vote share. In contrast, Garay (2016) argues that it is the electoral competition to obtain votes from the informal sector, rural workers, and unemployed that explains the expansion of social policies in Argentina, Brazil, Chile, and Mexico in the 1990s and 2000s. Similarly, Fairfield and Garay (2017) qualitatively show how electoral competition and social mobilizations motivated the expansion of redistributive policies under right-wing governments in Chile and Mexico.

Another strand of the literature on policy responsiveness analyzes the determinants of discretionary transfers allocation at the subnational level and consistently shows that the allocation of transfers is politically motivated. Examples include Brollo and Nannicini (2012) for Brazil and Porto and Sanguinetti (2001) for Argentina.

However, these studies do not explore heterogeneous responses to electoral competition, ponder the ideological distance among parties competing in elections, or consider nondiscretionary trans- 
fers as a mechanism to respond to voters ${ }^{1}$. I build on the premise that election results express the demands and preferences of the public (Powell, 2000) and propose a theory that addresses these gaps.

Historically, left-wing parties have aimed at more equal societies (Bobbio, 2004) and represented low-income people and working-class interests (Korpi, 1983). According to power resource theorists, unions and left parties contributed to the expansion of welfare policies (Korpi, 1983, 2006; Esping-Andersen, 1990). More recent evidence shows that left-wing parties tend to implement redistributive policies to enhance the economic conditions of their electorate (Morgan and Kelly, 2013). Likewise, left-wing governments are associated with a reduction of income inequality and this association holds even in the context of globalization (Ha, 2012). In the lower part of the income distribution, leftist governments redistribute via unemployment compensation, higher minimum wages, and strengthening the bargaining power of unskilled labor (Rueda, 2007). In the upper part, they do so through progressive taxes (Pontusson, Rueda and Way, 2002).

The distinction between Left and Right is pivotal for my argument. Different studies argue that the increasing concern with issues of recognition, identity, and liberalism has kept workers from voting for the left and, as a consequence, the left moving toward more conservative policies (Kriesi et al., 2008; Beramendi et al., 2015). However, these studies focus on developed countries. As opposed to these post-materialist concerns, Stokes (2001) and Campello and Zucco Jr (2016) claim that economic voting is of central relevance in the electoral competition in developing countries. Additionally, Debs, Helmke et al. (2010) show that economic inequality defines the electoral fortunes of left-wing candidates in Latin American countries.

Given that election results express the demands and preferences of the public, the vote share of

\footnotetext{
${ }^{1}$ Although Garay (2016) treats CCTs as nondiscretionary transfers, the expansion of CCTs is under the discretion of governments and it is usually tied to budget availability. What is nondiscretionary is the criteria to select the beneficiaries of the transfers.
} 
left-wing parties raises the salience of inequality and redistribution. However, left-wing candidates in multiparty competition vary in terms of ideological position and electoral strength.

To illustrate this point, imagine a theoretical presidential election with five candidates, two of them from the left. Although both left-wing candidates are expected to advance redistributive economic policies, one candidate might propose more radical policies (candidate $l_{r}$ ) than the other one (candidate $l_{m}$ ) to appeal to different demands of the public. Under this setting, $l_{r}$ is to the left of $l_{m}$. Likewise, the ideological distance between $l_{r}$ and a centrist candidate will be longer than the distance between $l_{m}$ and the same centrist candidate. The electoral performance of the leftwing candidates might be different as well. If the elected candidate is a non-leftist candidate and responds to the leftist support for redistribution, the elected candidate must weigh such support. To do so, the elected candidate can use the ideological position of $l_{r}$ and $l_{m}$ and their vote shares to know how radical and strong the supported redistribution was and respond accordingly.

The literature tends to focus on discretionary transfers as a mechanism of government responsiveness (Porto and Sanguinetti, 2001; Brollo and Nannicini, 2012). Yet, Litschig (2012) provides evidence on the political manipulation of nondiscretionary transfers in Brazil. The Fundo de Participação dos Municípios (Municipal Participation Fund) is a nondiscretionary transfer program that aims at redistributing income from rich to poor municipalities. Based on an allocation formula, the government shares revenue with local governments. However, Litschig (2012) finds a political manipulation of the population estimates in the formula in 1991, with swing-voter municipalities having a fictitious population increase. The fictitious population increase allowed the government to allocate more transfers to swing-voter municipalities. Likewise, Rozo and Vargas (2021) recently found that migration shocks increase central government nondiscretionary transfers to municipalities in Colombia.

Given that election results express the preferences of the public, left-wing parties vote shares 
indicate different levels of support for redistribution, and governments can respond to public preferences through nondiscretionary and discretionary transfers, I hypothesize the following:

H1 Governments increase nondiscretionary transfers as the public moves to the left side of the government ideological position.

H2 Governments increase discretionary transfers as the public moves to the left side of the government ideological position.

\section{Heterogeneous Responsiveness}

A relevant question is whether governments responsiveness is geographically heterogeneous. In developing countries, states have an uneven capacity over the territory (Migdal, 1988; Scott, 1998; Herbst, 2000) and voter turnout is heterogeneous at the subnational level (Besley and Burgess, 2002; Lehoucq and Wall, 2004). I argue that these factors condition government responsiveness.

Different studies show that the state capacity to collect taxes, deliver services, and provide institutional order varies at the subnational level (Ch et al., 2018; Garfias et al., 2018; Sanchez de la Sierra, 2020; Blattman et al., 2021; Peñaranda Currie, Otero-Bahamon and Uribe, 2021). While in some cases citizens rely on brokers and informal connections to compensate for the limited state capacity (Berenschot, 2019), there are other contexts in which non-state actors fill the vacuum of state order (Blattman et al., 2021; Peñaranda Currie, Otero-Bahamon and Uribe, 2021). My focus is on the latter.

Non-state actors with control over a territory and long-term goals provide socioeconomic order (Arjona, 2016; Sanchez de la Sierra, 2020) and undertake governance activities (Blattman et al., 2021). The illicit economic activities non-state actors rely upon involve the local population and have well-defined labor relations (Mejía and Rico Valencia, 2010). Non-state actors usually regulate 
the production, processing, and transportation of illicit goods produced in these territories. In addition, these actors collect taxes and provide public goods (Arjona, 2016; Sanchez de la Sierra, 2020).

Because the government is absent in such territories, non-state governance substitutes state governance. The order provided by non-state actors in these places breaks the chain of policy responsiveness. Although citizens express their preferences through voting, governments have limited capacity to adjust their nondiscretionary and discretionary policies in response to them.

H3 Governments' adjustment of nondiscretionary transfers is unresponsive to leftist support for redistribution in places where the government is absent.

H4 Governments' adjustment of discretionary transfers is unresponsive to leftist support for redistribution in places where the government is absent

Elections are a mechanism that allows citizens to express their policy preferences. During elections, citizens can vote or abstain from voting. When a citizen decides to vote, she shows a policy preference. In contrast, if a citizen chooses not to vote, she refrains from expressing a policy preference. Politicians cannot access ballots to learn about what voters want. In addition, politicians are limited in knowing the intensity of citizens' policy preferences. Regardless of how intense a citizens' preference is, her vote is one. However, at the aggregated level, politicians know if there are enough expressed preferences to respond. Places with low voter turnout are places where there are more indifferent voters in terms of policy preferences. Because politicians rely on votes to win elections and because low voter turnout implies more indifferent citizens in terms of political preferences, politicians have fewer incentives to respond to the electorate in places where voter turnout is low. Existing studies show that higher electoral participation leads governments to increase social spending and transfers (Besley and Burgess, 2002; Boix et al., 2003). I draw on 
these findings and hypothesize the following:

H5 Government responsiveness to leftist support for redistribution through nondiscretionary transfers decreases with higher levels of voters abstention.

H6 Government responsiveness to leftist support for redistribution through discretionary transfers decreases with higher levels of voters abstention.

\section{Research Design: The Colombian Case}

In this paper, I use data on the 2006, 2010, 2014, and 2018 presidential elections, over 12 years of central government transfers from 1,122 municipalities, and more than four million administrative records of a CCT program in Colombia to empirically test the policy responsiveness argument. There are several features of this case that make it an ideal setting for testing policy responsiveness.

Colombia is a unitary state divided between 32 departments (administrative states) that group over 1000 municipalities. There are democratically elected officials at each level of political authority. The people directly elect the president every four years through general elections. A candidate wins the presidential race with half plus one of the ballots, or in a runoff election between the two most voted candidates if any of them reached the $50 \%$ plus one vote in the first round. Since the Political Constitution of 1991, the electoral system opened to political competition beyond the two traditional parties. This democratic openness derived into a multiparty system, allowed new political forces to compete for office and provided voters with a more broad set of ideological options. Although no left-wing candidate has won office so far, former left-wing guerrillas combatants have been frontrunner candidates in past elections, thus generating a salient left-right political cleavage.

At the sub-national level, there are regional elections where people elect governors and mayors, who then take office at the departmental and municipal levels, respectively. The presidential 
election takes place one year before (or three years after) the regional elections. Although municipalities can implement and collect taxes within their jurisdiction, most of their revenue comes from the central government transfers. In 2001, the government established a transfer system with a redistributive goal, to close the social and economic gaps between municipalities. Since 2002, municipalities receive annual government transfers based on their population, poverty level, and demand for schooling and health. Around $80 \%$ of the transfers are assigned to education and health at the municipal level.

In addition to the transfer system, the government created Familias en Accion in 2001, a CCT program aimed at alleviating and reducing poverty in 350 municipalities. The program targets families in poverty or extreme poverty as well as families displaced by the armed conflict. The cash transfer is conditional on recurrent children's medical checks and school attendance. While the central government transfers to municipalities rely on the central government revenue, the CCT targets individuals and is funded by the government, the World Bank, and the Inter-American Development Bank. In 2012, the government expanded the CCT program to all municipalities (DPS, 2019). Although there are specific selection criteria of potential beneficiaries of Familias en Accion, the number of potential beneficiaries is under the government discretion.

Colombia provides geographical heterogeneity in levels of state control over the territory and political abstention. Colombia has territories with coca crops that have been historically controlled by non-state actors (Peceny and Durnan, 2006). Because coca is an illegal crop, the order necessary for its economy to work is provided by non-state armed actors. As Peñaranda Currie, Otero-Bahamon and Uribe (2021) point out, the expansion of the coca economy generated a gap of institutional order that was filled by the Colombian Revolutionary Armed Forces (FARC in Spanish). The peace agreement between the Colombian government and the FARC in 2016 highlighted the state abandonment in territories with coca crops. Moreover, there is noncompulsory voting in 
Colombia. The level of abstention in presidential elections varies across municipalities and over time (see Figure S6).

The heterogeneous political ideologies of presidential candidates, the cross-municipal variation in government transfers, and the different state presence and level of electoral abstention over the territory provide variation on the key features or the policy responsiveness argument.

I aim to investigate whether the central government responds to the leftist support for redistribution. To do so, I focus on central government transfers to education and public health at the municipal level. Likewise, I use the number of beneficiaries of the CCT program by municipality to test for responsiveness through a discretionary mechanism.

The central government transfers are redistributive by design and provide more benefits to the poor, who are more likely to use public education and health. Although municipal authorities implement the transfers, they have no control over the allocations, it is the central government that delineates and oversees the spending. While transfers are expected to rely on specific criteria, there is qualitative evidence on the flexible use the government makes from such transfers (see Bonet and Galvis, 2016; El Tiempo, 2017). Moreover, Rozo and Vargas (2021) recently found that migration shocks increase central government transfers to municipalities.

Personal interviews with experts suggest that the government has room to modify transfers. Experts confirmed that specific criteria determine transfers, being population and level of unsatisfied basic needs the most relevant ones. However, they affirmed that the government makes minor methodological adjustments to the formula that determines transfers. In addition, experts from the National Planning Department maintained that the government adjusts transfers for the year $t$ in December of year $t-1$ based on budget availability. Moreover, experts explained that it is the government that provides the data to estimate the transfers. Likewise, the government, rather 
than an independent agency, sends the transfers to municipalities ${ }^{2}$.

Similar to my research design, Archibong et al. (2021) use central government transfers to subnational entities as a measure of policy responsiveness. They find that protests increase the amount of transfers the central government sends to subnational entities.

\section{Empirical Strategy: Data and Models}

\section{Main Outcomes}

To test whether there is policy responsiveness, I collected two sets of administrative data. First, I collected data at the municipal-year level on central government transfers to education and public health between 2006 and 2019 to evaluate responsiveness through nondiscretionary transfers. Governments can respond to the electorate distance after being elected $(t+1)$ or before the next presidential election $(t+3)$. Because nondiscretionary transfers growth over time depends on central government revenue, I expect that governments respond during the first year they can adjust transfers $(t+1)$ given the uncertainty about future available funds to respond to the electorate distance. I use central transfers at $t+1$ in constant values as the dependent variable. The data on transfers come from the National Department of Planning, and it is publicly available information.

The second dataset includes the number of beneficiaries of the CCT program at the municipalquarter level between the last quarter of 2012 and the last quarter of 2018. This dataset allows me to test whether there is responsiveness through discretionary transfers. Because an elected government takes office in August, I aggregated the number of beneficiaries enrolled during the last five months of 2014 and the last five months of 2018 in each municipality. Since the last available

\footnotetext{
${ }^{2}$ Online interview with author, 2 July 2021.
} 
data is for December 2018, I focus on this time frame to compare equivalent periods. I use the aggregated data as the dependent variable. The data on beneficiaries come from the Department of Social Prosperity and is publicly available. I log-transformed both outcome variables to reduce the skewness of the distribution.

\section{Main Explanatory Variable}

In my analysis, I build a measure of electorate distance from the government ideological position to assess the leftist support for redistribution. The electorate distance is the municipal-level deviation of the electorate to the left of the central government ideology. Put another way, it is a standardized measure of how far to the left the electorate is at the municipal level, compared to the president's ideology. My measure captures the relative weight of the candidates by multiplying their ideological position with their vote shares within municipalities. The electorate distance is:

$$
\left(\sum_{c=1}^{n} \text { Ideology }_{c} * \text { Voteshare }_{c}\right)-\text { Ruling Party Ideology }
$$

where $c$ is the subscript for candidates. I use Baker and Greene's data (2011) to measure candidates' ideology. The ideological scores go from 1 (far left) to 20 (far right), then positive values imply an electorate to the right of the ruling party ideological position. I invert the variable scale in the analysis to interpret results in terms of left-leaning electorates. Baker and Green rely on Wiesehomeier and Benoit (2009), Pop-Eleches (2008), Coppedge (1998), and surveys of experts to measure and standardize the ideology of parties and candidates in Latin American countries between 1995 and 2015. The main advantage of this dataset is that it not only measures the ideology of presidents but also presidential candidates. However, the ideological position of 
candidates is fixed over time. Candidates that run in several elections are assumed to keep their ideological positions over time. Therefore, the variation in my analyses comes from the different electorate distances in municipalities. To my knowledge, this is the only dataset on Latin American politicians that measures the ideology of presidential candidates.

\section{Control Variables}

In the regressions where the dependent variable is central government transfers per capita, I use as control variables the criteria the government employs to determine the amount of transfers to education and health: total population, education coverage, education enrollment, unsatisfied basic needs, unvaccinated population, and a rurality index (DNP, 2019). These data are also reported by the National Department of Planning.

Because the Colombian armed conflict and its legacies may affect how people vote in the national elections and the criteria to assign transfers, I control for demobilized guerrilla combatants, displaced population, violent threats, presence of coca crops, and the number of homicides. I collected these data from CEDE. Additionally, I use income growth per capita, a fiscal performance index, and the number of people in tertiary education as additional controls to improve the efficiency of my estimates.

The CCT program Familias en Acción targets low-income families and requires that municipalities have the infrastructure to provide health and education. Therefore, regressions estimating the effect of the electorate distance on the number of CCT beneficiaries control for the number of households registered in the System of Identification of Social Program Beneficiaries (SISBEN), the number of schools, and the number of health centers. In addition, I control for conflict-related variables, population size, income growth per capita, students in primary school, the share of the population living in rural areas, fiscal performance, and unsatisfied basic needs. 


\section{Empirical Model}

Since the electoral distance is measured on election years and stays constant over the presidential term, I use municipality-election year as unit of analysis. Although an annual periodization in the panel would increase the statistical power of the analysis, the literature suggests that an electionyear periodization is more suitable for partisan models (Schmitt, 2016) ${ }^{3}$. To test the effect of the electorate distance on central government transfers, I use this periodization and estimate an OLS two-way fixed effects (TWFE) regression with the following specification:

$$
y_{i t+1}=\alpha_{i}+\zeta_{t}+\beta D_{i t}+\lambda X_{i t-1}+\epsilon_{i t},
$$

where $y$ are transfers to public health and education per capita in municipality $i$ and $t$ indicates the election year. $\alpha_{i}$ are municipality fixed effects, $\zeta_{t}$ are year fixed effects, and $X_{i t-1}$ is the matrix of time-varying covariates measured the year before the election. The term $D_{i t}$ is the variable of interest, the electorate distance. Based on the policy responsiveness argument, I expect the coefficient $\beta$ to be positive. My identifying assumption with this strategy is that electorate distance is conditionally independent of transfers within presidential terms. To test the effect of the electorate distance on the number of CCT beneficiaries, I follow a similar strategy, but I set $y$ at $t$ rather than $t+1$ given the lack of data for 2019 .

Recent methodological research shows that estimates from TWFE models are likely to be biased when the treatment is implemented in multiple periods. In these settings, treatment effects can change over time within treated units, but TWFE is not robust to such heterogeneity (GoodmanBacon, 2021; Callaway and Sant'Anna, 2020). However, TWFE works when the treatment effect does not change across different periods. I employ Jakiela's (2021) diagnostics and prove that the

\footnotetext{
${ }^{3}$ Recent work follows this approach. See Schmitt and Zohlnhöfer (2019) and Garritzmann and Seng (2020).
} 
effect of electorate distance does not change across elections (see TWFE Diagnostics in SI.).

\section{Results}

\section{Government Transfers}

Figure 1 presents my findings of the effect of electorate distance on central government transfers. All models include control variables and municipality and year fixed effects. In line with the policy responsiveness argument and consistent with my first hypothesis, the effect of electorate distance on government transfers is positive. As expected, the regression coefficient of the electorate distance is positive and statistically different from 0 at $t+1$ but not in other periods. Results indicate that municipalities that are one standard deviation to the left of the government ideological position receive higher transfers from the central government. Specifically, figure 1 shows that central government transfers are 2.8 percent higher at $t+1$ in municipalities that are one standard deviation to the left of the government ideological position.

\section{Discretionary Transfers}

A particular feature of my analysis is that it distinguishes between nondiscretionary and discretionary government transfers. While the government has less room to modify the former, it can expand the latter at discretion. I explore whether there is responsiveness through discretionary transfers. In particular, I test if the number of CCT beneficiaries increases in municipalities that are at the left of the government ideological position.

Consistent with my second hypothesis, figure 2 shows that there is responsiveness through discretionary transfers. Models 1 and 2 include municipality and year fixed effects. Model 1 


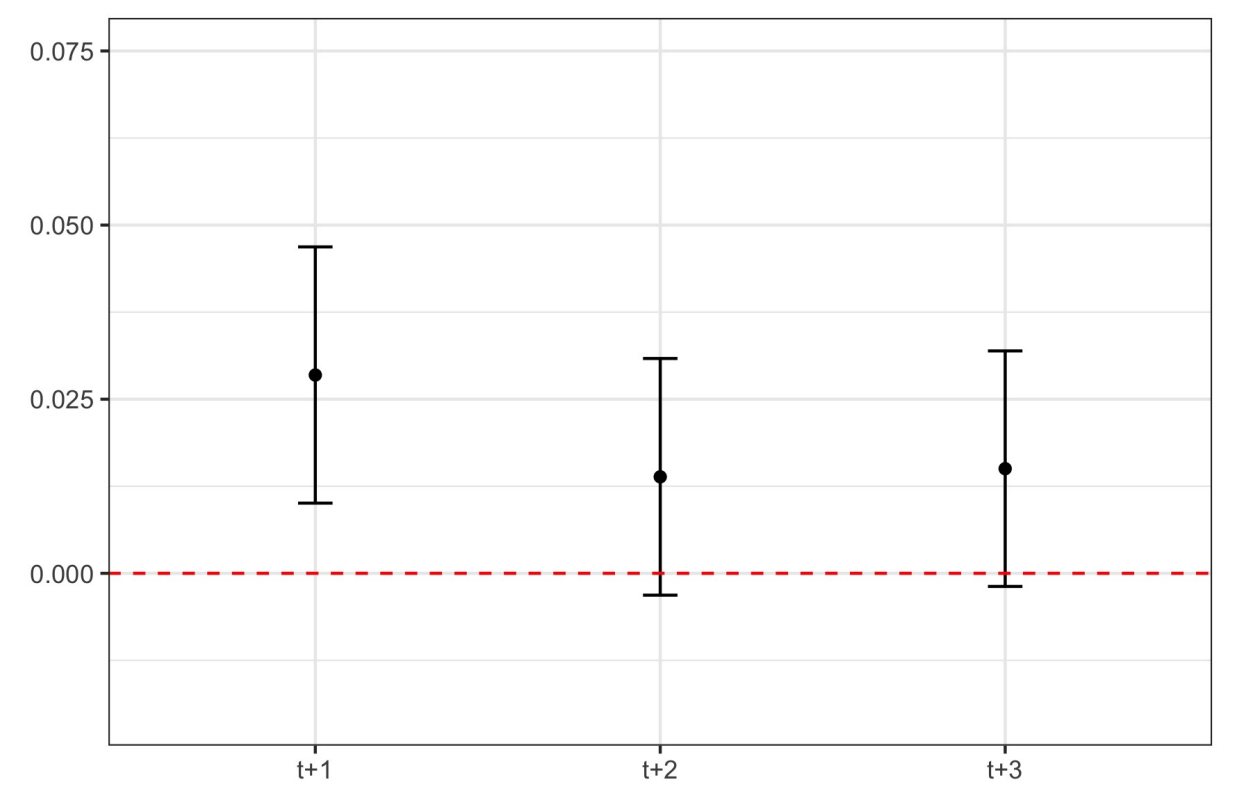

Figure 1: Log Government Transfers Per Capita.

Note. OLS estimates with $95 \%$ CI regressing logged government transfers per capita on electorate distance. The models include municipality and year fixed effects using standard errors clustered at the municipal level. Regressions reported in table S4, in SI.

reports the effect of electorate distance on the log number of CCT beneficiaries without control variables. The effect is positive and holds when I include controls: a one-unit increase in the electorate distance is associated with a 20.7 percent increase in the number of CCT beneficiaries $\left(\right.$ Model 2) ${ }^{4}$. A relevant determinant of discretionary transfers is the level of unsatisfied basic needs. The confounding effect of such a variable is absorbed by the municipality fixed effects in models 1 and 2. I remove municipality fixed effects in Model 3 and include unsatisfied basic needs as a control. As expected, the effect is positive and statistically different from 0 .

\section{Government Transfers - Heterogeneous Effects}

In developing countries, the state has an uneven presence over the territory (Herbst, 2000; Ch et al., 2018). Colombia, in particular, has territories with coca crops that have been historically controlled by non-state actors (Peceny and Durnan, 2006). The characteristics of coca crops

\footnotetext{
${ }^{4}$ In Supplementary Information S1, I provide evidence for the robustness of these results.
} 


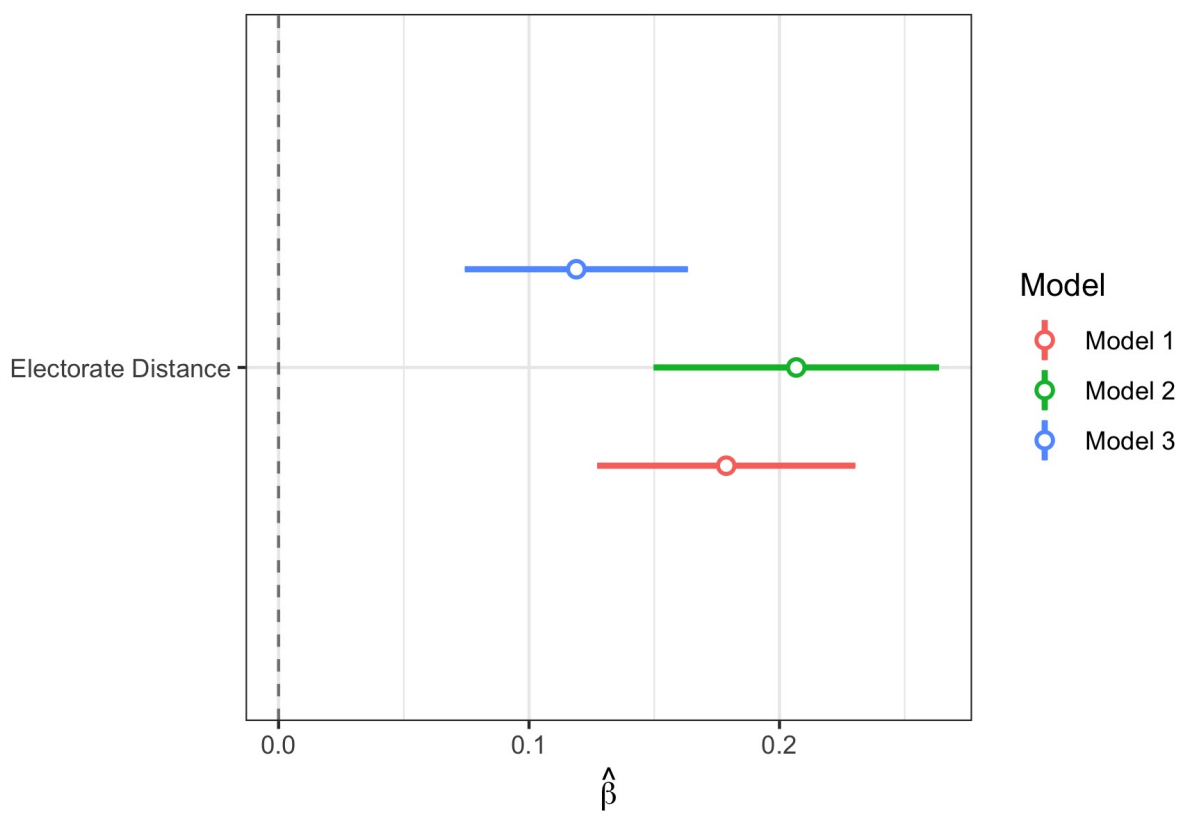

Figure 2: Log CCT Beneficiaries.

Note. OLS estimates with $95 \%$ CI regressing logged CCT beneficiaries on electorate distance. Models 1 and 2 include municipality and year fixed effects. Model 3 includes year fixed effects. All models use standard errors clustered at the municipal level. Regressions reported in table S6, in SI.

allow inhabitants of such territories to develop economies with well-defined labor relations and high amounts of money (Mejía and Rico Valencia, 2010). Because coca is an illegal crop, the order necessary for its economy to work is provided by non-state actors. Non-state actors usually regulate the production, processing, and transportation of coca. They structure and organize labor, collect taxes, and provide public goods (Arjona, 2016). As Peñaranda Currie, Otero-Bahamon and Uribe (2021) point out, the expansion of the coca economy generated a gap of institutional order that was filled by the Colombian Revolutionary Armed Forces (FARC in Spanish). The peace agreement between the Colombian government and the FARC in 2016 highlighted the state abandonment in territories with coca crops.

A relevant question is whether the government is more or less responsive to the electorate distance in municipalities with coca crops. Figure 3 shows the estimated effect of electorate distance by coca crops. I use the same specification as in Figure 1 and split the data into two groups: 
municipalities with and without coca crops. Consistent with my third hypothesis, the effect of electorate distance is concentrated in municipalities without coca crops and is null in municipalities with coca crops. While the differences between both groups of municipalities are estimated under several controls, I maintain that such differences cannot be associated with municipality- or timeinvariant characteristics.

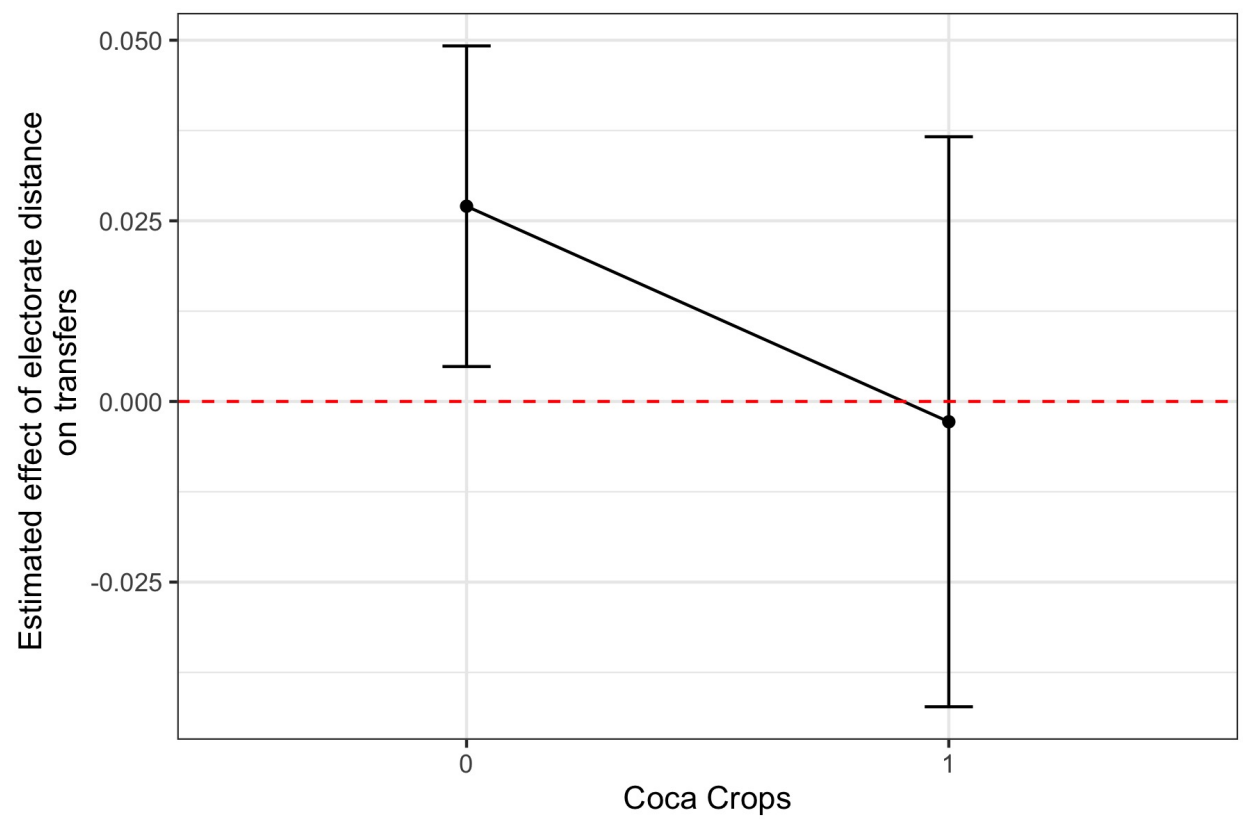

Figure 3: Heterogeneous Effect of Electorate Distance.

Note. Estimated effect of electorate distance on the logged government transfers per capita, by presence of coca crops. The regression includes municipality and year fixed effects using standard errors clustered at the municipal level. Regression reported in table S5 in SI.

Another source of heterogeneous responsiveness is abstention. Because citizens express their preferences through elections, the government will be less responsive in municipalities with higher levels of abstention. Figure 4 shows that there is empirical support for my fifth hypothesis: The marginal effect of the electorate distance on central government transfers decreases with the level of abstention. 


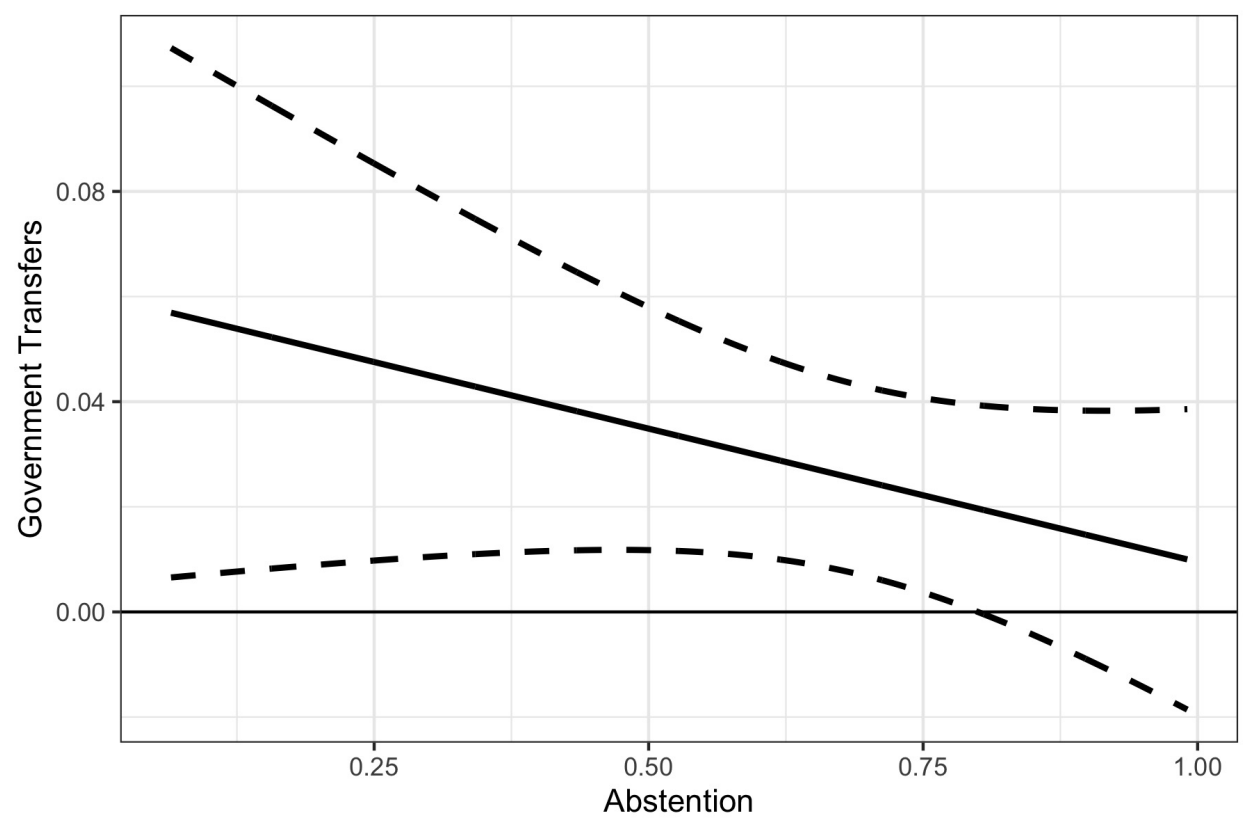

Figure 4: Heterogeneous Effect of Electorate Distance.

Note. Estimated effect of electorate distance on the logged government transfers per capita, by level of electoral abstention. The regression includes municipality and year fixed effects using standard errors clustered at the municipal level. Regression reported in table S5 in SI.

\section{Discretionary Transfers - Heterogeneous Effects}

In addition, I estimate whether there is heterogeneous responsiveness to the electorate distance. As with the central government transfers, responsiveness is heterogeneous: responsiveness is null in municipalities with coca crops (5) and responsiveness decreases with the level of abstention (6). Both of these findings provide empirical support for my hypotheses 4 and 6 , respectively.

\section{Responsiveness in Latin America}

I investigate whether there is policy responsiveness at the country level using data from over 90 national elections in 18 Latin American countries between 1995 and $2018{ }^{5}$. There are several reasons to use this sample. First, in 1995 the different dictatorships that had been ruling countries like Argentina, Bolivia, Chile, and Uruguay already ended and the subsequent introduction of

\footnotetext{
${ }^{5}$ Summary statistics and countries are reported in the SI.
} 


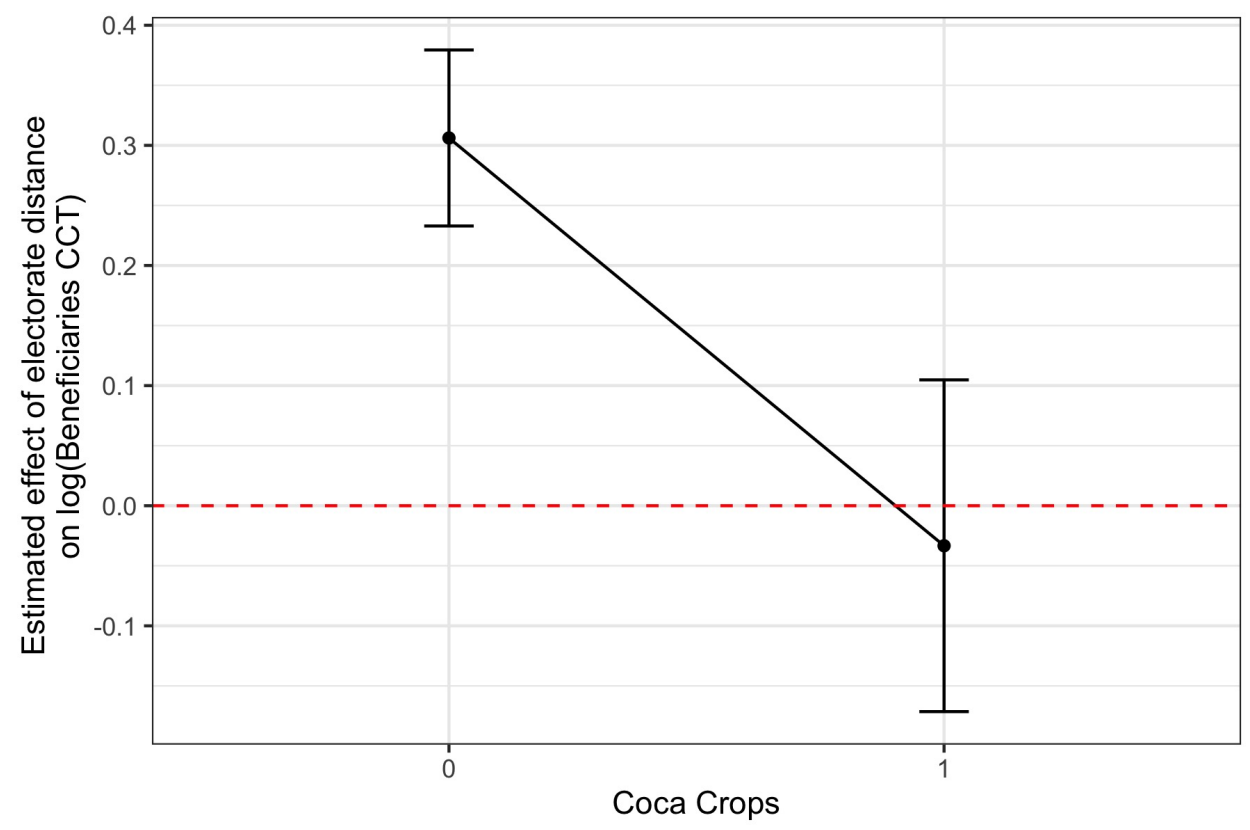

Figure 5: Heterogeneous Effect of Electorate Distance.

Note. Estimated effect of electorate distance on the logged CCT beneficiaries, by presence of coca crops. The regression includes municipality and year fixed effects using standard errors clustered at the municipal level. Regression reported in table S7 in SI.

elections allowed voters to express their political preferences (Hagopian and Mainwaring, 2005). Second, left-wing parties became electorally stronger, particularly in the first decade of this century (Baker and Greene, 2011; Debs, Helmke et al., 2010). Finally, during this period most of these countries experienced a decline in the level of inequality (López-Calva and Lustig, 2010). In short, this sample provides cross-country and over time variation at both sides of the equation.

To examine responsiveness at the country level, I rely on two features of my previous analysis, the ideological difference across presidential candidates and the redistributive nature of the nondiscretionary transfers. Although not all countries have unitary states and data on government transfers are scarce at the country level, I lean on the redistributive design of central government transfers in Colombia. Therefore, I use average redistribution ${ }^{6}$ by presidential term rather than transfers to test the policy responsiveness argument across Latin American countries. Redistribu-

\footnotetext{
${ }^{6} \mathrm{I}$ use average redistribution rather than redistribution at $t+1$ because redistribution takes time to vary.
} 


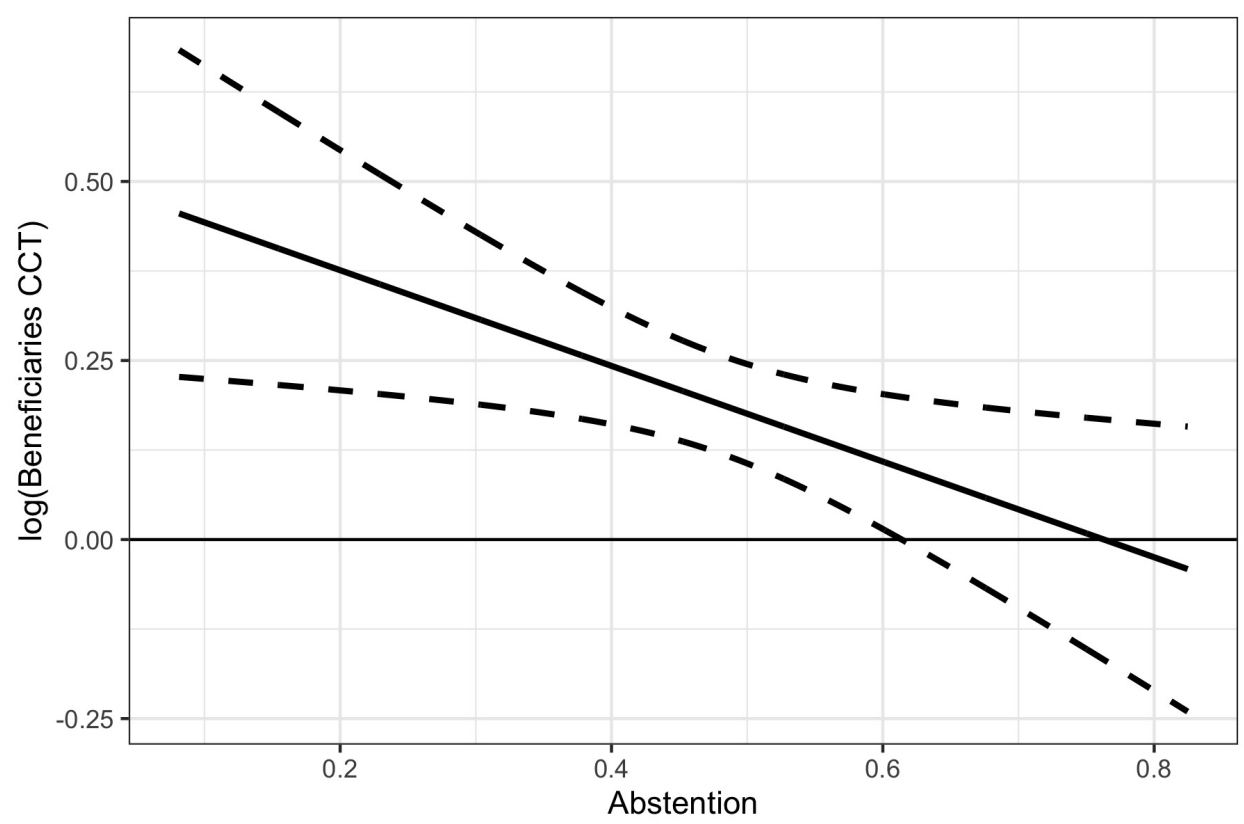

Figure 6: Heterogeneous Effect of Electorate Distance.

Note. Estimated effect of electorate distance on the logged CCT beneficiaries, by level of electoral abstention. The regression includes municipality and year fixed effects using standard errors clustered at the municipal level. Regression reported in table S7 in SI.

tion is estimated as the difference between the Gini of market income and the Gini of disposable income. Given that disposable income includes state transfers, I can have a good proxy of redistribution via policies. I use the standardized measures of Gini of the market and disposable incomes computed by Solt (2016) to define the redistribution variable. In this way, higher values mean more redistribution.

For the electorate distance calculation, I use Baker and Greene's data (2011) and follow the same approach as in the Colombian case. A distinctive feature of my analysis is that it looks for the effect of the electorate distance controlling for the government's ideology to test whether this effect operates independently of who holds office. Therefore, in the regressions I have controlled by government ideology, as measured by Baker and Greene (2011). Additionally, my regressions included a set of lagged controls that may affect electorate distance. By using lags, I can be certain that these variables are potential causes rather than consequences of the electorate distance since 
they are measured at $t-1$ and the electorate distance is measured at $t$. The lagged controls are terms of trade, inflation, unemployment, education, GDP per capita, the proportion of elderly, Gini of market income, legal opposition to the executive power, economic growth, and external debt.

Because higher terms of trade relax economic constraints, fiscal discipline, and opposition to redistribution (Campello, 2015), left-wing parties may increase their vote share when the terms of trade rise. I control for terms of trade as measured by UNCTADstat to discount the effect of the commodity boom experienced in Latin America in the first decade of this century. Because hyperinflation has been usually associated with left-wing governments and jeopardized the electoral fortunes of left-wing parties (Sader, 2011), I control for inflation using data from CepalStat. Leftwing parties generally include unemployment compensations in their policy agendas (Rueda, 2007), consequently, higher rates of unemployment may increase the left vote. I use data from the International Labor Organization (ILO) to control for unemployment. Provided that the level of education may affect the vote for the left, I control for education using data from Barro and Lee (2013). I include the log-transformed GDP per capita as routine control to discount the effect that economic development may have on the left vote share as well as on redistribution. I employ data from the World Bank to measure GDP per capita.

In the regressions, I also included the lagged value of trade openness as a proxy of globalization. Although the electorate distance may not depend on this variable, globalization might be correlated with my dependent variable. Philips, Souza and Whitten (2020) find that globalization affects the distribution of income across quintiles depending on the relative factor endowment of each country. In labor-rich countries such as the Latin American ones, globalization increases the income share of the lower quintiles at the expense of the top quintile, thus affecting the overall income distribution. I collected the data on trade openness from the World Bank database. I also control for the 
proportion of the elderly population as measured by the World Bank since a higher proportion of the elderly may increase redistribution. I control for inequality at the market level to discount the Meltzer-Richard prediction that more inequality will be associated with more redistribution (Meltzer and Richard, 1981). I employ the measure of Gini of market income, as measured by Solt (2016). Finally, I include a measure of legal opposition to government and external debt as calculated by Varieties of Democracies (Coppedge et al., 2019) and CepalStat, respectively. Opposition to the government might limit the redistributive policies that it plans to implement. On the other hand, economic growth may allow governments to advance redistributive agendas.

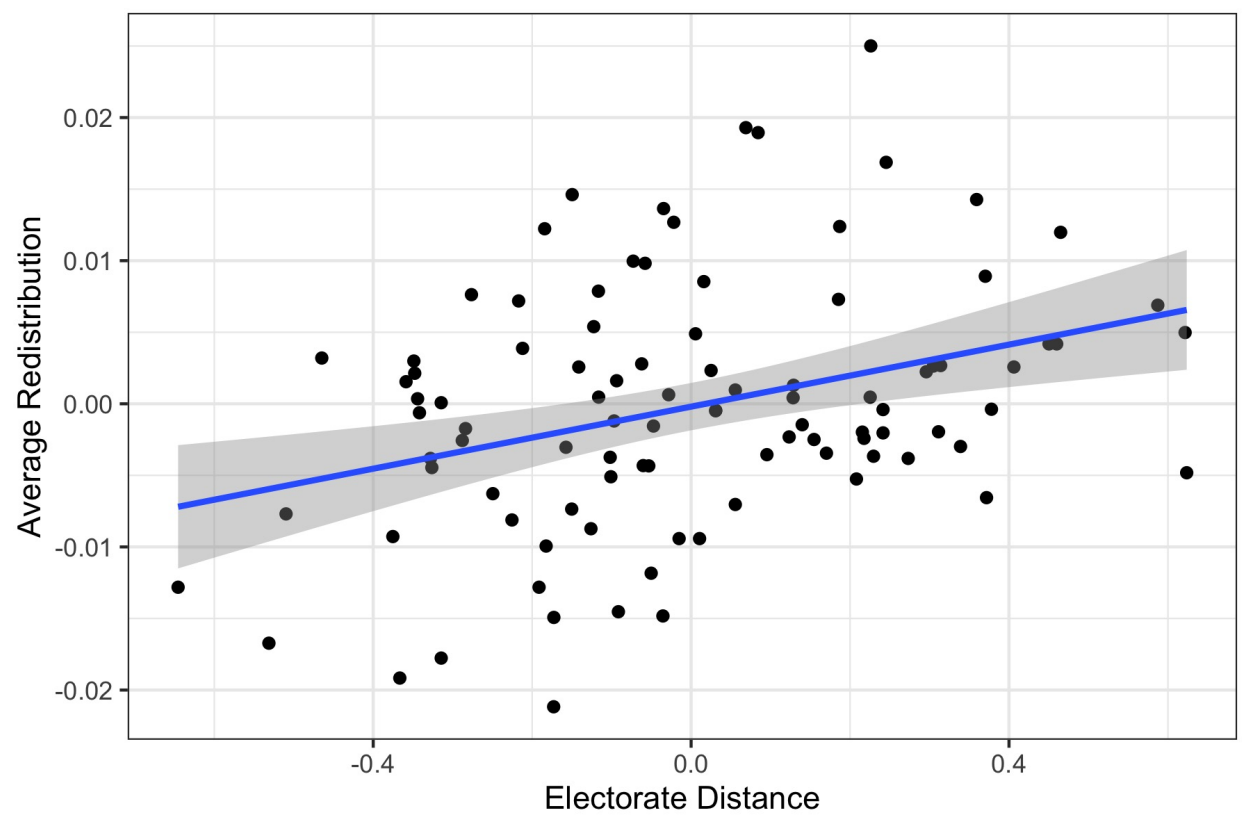

Figure 7: Residual Plot - Country-level data.

Note. Greater values in the x-axis mean electorates more to the left of the president's ideology.

As figure 7 illustrates, electorate distance is associated with more redistribution. Table 1 presents the results of OLS regressions on average redistribution. I used bootstrapped simulations to obtain standard errors clustered by country. This approach provides a more accurate inference than the usual cluster-robust standard errors when there is a low number of clusters (Cameron, Gelbach and Miller, 2008). The extended regression tables are reported in the supplementary 
information.

Table 1 indicates that there is policy responsiveness in Latin American countries. Column 1 shows that one standard deviation to the left of the government ideology increases average redistribution by 0.014 points. Column 2 presents the results using country-year units of analysis. This approach allows me to include the year as a running variable in the models and estimate an OLS two-way fixed effects, thus discounting idiosyncratic and time trend effects on the associations of interest ${ }^{7}$. The result is consistent with the country-election regression.

Table 1: Electorate Distance Effect on Average Redistribution. Country-level Panel

\begin{tabular}{lcc}
\hline & 1 & 2 \\
\hline Electorate Distance & $0.014^{*}$ & $0.010^{*}$ \\
& $(0.005)$ & $(0.004)$ \\
\hline Country FE & Yes & Yes \\
Year FE & Yes & No \\
Num. Obs. & 92 & 435 \\
\hline${ }^{* * *} p<0.001 ;{ }^{* *} p<0.01 ;{ }^{*} p<0.05$. & OLS estimates. \\
Bootstrapped SE's clustered by country.
\end{tabular}

\section{Robustness Tests}

Empirical research with observational data implies several challenges and limitations. One of the main concerns in these analyses is the omitted variable bias. Although my regressions include several controls, there are unobserved variables that might be affecting the relation between electorate distance and the outcome variables. I follow Cinelli and Hazlett (2020) and conduct sensitivity analyses to assess the robustness of my findings on Colombia to omitted variables. The results from the sensitivity analyses are reported in the supplementary information and indicate that my results are robust to omitted variables (see Robustness Checks). Additionally, I show that the

\footnotetext{
${ }^{7}$ Because the electorate distance in a given national election does not vary until the next election, I set all variables following the time structure in the country-election panel, but now I let $t$ to be a running variable.
} 
effect of electorate distance on nondiscretionary transfers holds after removing from the analysis the municipalities with extreme values in reported transfers (see S9 in SI.).

My analysis of responsiveness through nondiscretionary transfers relies on completed presidential terms. Importantly, TWFE diagnostic shows that the effect of electorate distance is homogeneous over time (see TWFE Diagnostics). However, when I expand the analysis to include available data for the current government (2018-2022), I find that the effect of electorate distance on nondiscretionary transfers is statistically indistinguishable from 0 . I posit that there is a plausible explanation for this. In 2018, Gustavo Petro, a former guerrilla member, advanced to the second round of the presidential elections as the left-wing candidate. It was the first time in Colombian history the establishment faced a credible electoral threat from the left. I contend that under this scenario, a government strategy to penalize leftist support for redistribution substitutes policy responsiveness. Therefore, a TWFE estimation of the effect of the electorate distance is inaccurate as this effect might vary in 2018. Specifically, the inclusion of 2018 in the TWFE estimation washes out the average electorate distance effect found in previous elections. If my assumption about 2018 is plausible, I should observe a negative effect of the electorate distance on nondiscretionary transfers in 2018. Table S10 shows that the effect of electorate distance is negative and significant in 2018.

\section{Conclusions}

Existing studies for developing democracies show that governments adjust their policies in response to factors like electoral competition and public policy preferences. For example, governments implement or expand social programs when they face electoral competition. In this paper, I show that governments are responsive to voters ideological preferences as well. However, responsiveness 
is heterogeneous. Indeed, I advance and empirically test an argument that builds on the ideological difference between left- and right-wing presidential candidates and accounts for heterogeneous responsiveness. I argue that elected officials learn about the distribution of voters ideological preferences and respond accordingly. Specifically, elected officials increase redistributive transfers in places where the electorate leans to the left of the ideological spectrum. However, responsiveness is conditional on state control of the territory and electoral abstention. Responsiveness is null in places where non-state actors control the territory. Likewise, responsiveness decreases with voters abstention.

To empirically test my theory, I take the case of Colombia, a developing democracy where the left-right political distinction is salient. Using a two-way fixed-effects estimation and administrative data on government transfers, I find that governments increase nondiscretionary and discretionary transfers as the leftist support for redistribution increases. Importantly, I show that responsiveness is heterogeneous: there is no government responsiveness in places controlled by non-state actors, and responsiveness decreases with voters abstention. Using a panel of Latin American countries, I further find that in countries where the electorate is at the left side of the government ideological position, governments redistribute more.

My findings are robust to a series of additional tests, and they can inform the renewed interest in government responsiveness (see Grossman and Slough, 2022) by pointing to the conditions under which policy responsiveness holds as well as the mechanisms government use to respond. Importantly, my findings have implications for subnational socioeconomic inequalities as unequal responsiveness might further exacerbate subnational disparities.

My extended analysis of the Colombian case suggests that the direction of the government responsiveness might change. In the presence of a credible leftist threat, the elected government might choose to penalize the leftist electorate. Further research must explore when and how gov- 
ernments change the direction of the response. Likewise, future research ought to assess to what extent runoff elections with a credible leftist electoral threat break the chain of responsiveness. Another important avenue for future research is inequality in accountability. For instance, what does unequal responsiveness imply about how democratic accountability operates at the subnational level?

While I address external validity concerns with the country-level analysis, the heterogeneous responsiveness within countries must be further researched. There are reasons to expect similar findings in other Latin American countries given that uneven state presence over the territory is a shared characteristic. However, it is unclear whether the effect of voters abstention will hold in countries with mandatory voting. Likewise, future research must explore other factors that might as well condition responsiveness. For instance, social protests and ideological ties with local politicians might attenuate government responsiveness. 


\section{References}

Archibong, Belinda, Tom Moerenhout, Evans Osabuohien and Francis Annan. 2021. "Protest matters: The redistributive effects of protests on intergovernmental transfers.".

Arjona, Ana. 2016. Rebelocracy. Cambridge University Press.

Baker, Andy and Kenneth F Greene. 2011. "The Latin American left's mandate: free-market policies and issue voting in new democracies." World Politics 63(1):43-77.

Barro, Robert J and Jong Wha Lee. 2013. "A new data set of educational attainment in the world, 1950-2010." Journal of development economics 104:184-198.

Beramendi, Pablo, Silja Häusermann, Herbert Kitschelt and Hanspeter Kriesi. 2015. The politics of advanced capitalism. Cambridge University Press.

Berenschot, Ward. 2019. "Informal democratization: brokers, access to public services and democratic accountability in Indonesia and India." Democratization 26(2):208-224.

Besley, Timothy and Robin Burgess. 2002. "The political economy of government responsiveness: Theory and evidence from India." The quarterly journal of economics 117(4):1415-1451.

Blattman, Christopher, Gustavo Duncan, Benjamin Lessing and Santiago Tobón. 2021. Gang rule: Understanding and Countering Criminal Governance. Technical report National Bureau of Economic Research.

Bobbio, Norberto. 2004. Destra e sinistra: ragioni e significati di una distinzione politica. Vol. 65 Donzelli Editore.

Boix, Carles et al. 2003. Democracy and redistribution. Cambridge University Press.

Bonet, Jaime and Luis Armando Galvis. 2016. Sistemas de transferencias subnacionales: lecciones para una reforma en Colombia. Banco de la República-Colombia.

Brollo, Fernanda and Tommaso Nannicini. 2012. "Tying your enemy's hands in close races: the politics of federal transfers in Brazil." American Political Science Review 106(4):742-761.

Callaway, Brantly and Pedro HC Sant'Anna. 2020. "Difference-in-differences with multiple time periods." Journal of Econometrics .

Cameron, A Colin, Jonah B Gelbach and Douglas L Miller. 2008. "Bootstrap-based improvements for inference with clustered errors." The Review of Economics and Statistics 90(3):414-427.

Campello, Daniela. 2015. The politics of market discipline in Latin America: globalization and democracy. Cambridge University Press. 
Campello, Daniela and Cesar Zucco Jr. 2016. "Presidential success and the world economy." Journal of Politics 78(2):589-602.

Ch, Rafael, Jacob Shapiro, Abbey Steele, Juan F Vargas et al. 2018. "Endogenous taxation in ongoing internal conflict: The case of Colombia." American Political Science Review 112(4):9961015 .

Cinelli, Carlos and Chad Hazlett. 2020. "Making sense of sensitivity: Extending omitted variable bias." Journal of the Royal Statistical Society: Series B (Statistical Methodology) 82(1):39-67.

Coppedge, Michael. 1998. "The dynamic diversity of Latin American party systems." Party Politics $4(4): 547-568$.

Coppedge, Michael, John Gerring, Carl Henrik Knutsen, Staffan I Lindberg, Jan Teorell, David Altman, Michael Bernhard, M Steven Fish, Adam Glynn, Allen Hicken et al. 2019. "V-dem codebook v9.".

Debs, Alexandre, Gretchen Helmke et al. 2010. "Inequality under democracy: explaining the left decade in Latin America." Quarterly Journal of Political Science 5(3):209-241.

DNP. 2019. Guía para la Distribución de los Recursos del Sistema General de Participaciones. Technical report Departamento Nacional de Planeación.

DPS. 2019. Manual Operativo. Familias en Acción. Technical report Departamento para la Prosperidad Social.

El Tiempo. 2017. "Los cinco huecos del Sistema que busca reducir la inequidad.".

URL: https://www.eltiempo.com/justicia/investigacion/contraloria-presenta-fallas-del-sistemageneral-de-participaciones-92074

Esping-Andersen, Gosta. 1990. The three worlds of welfare capitalism. Princeton University Press.

Fairfield, Tasha and Candelaria Garay. 2017. "Redistribution under the right in Latin America: Electoral competition and organized actors in policymaking." Comparative Political Studies 50(14):1871-1906.

Garay, Candelaria. 2016. Social policy expansion in Latin America. Cambridge University Press.

Garfias, Francisco et al. 2018. "Elite competition and state capacity development: Theory and evidence from post-revolutionary Mexico." American Political Science Review 112(2):339-357.

Garritzmann, Julian L and Kilian Seng. 2020. "Party effects on total and disaggregated welfare spending: A mixed-effects approach." European Journal of Political Research 59(3):624-645.

Golden, Miriam and Brian Min. 2013. "Distributive politics around the world." Annual Review of Political Science 16:73-99. 
Gonschorek, Gerrit J, Günther G Schulze and Bambang Suharnoko Sjahrir. 2018. "To the ones in need or the ones you need? The political economy of central discretionary grants- empirical evidence from Indonesia." European Journal of Political Economy 54:240-260.

Goodman-Bacon, Andrew. 2021. "Difference-in-differences with variation in treatment timing." Journal of Econometrics .

Grossman, Guy and Tara Slough. 2022. "Government Responsiveness in Developing Countries." Annual Review of Political Science 25(1).

Ha, Eunyoung. 2012. "Globalization, government ideology, and income inequality in developing countries." Journal of Politics 74(2):541-557.

Hagopian, Frances and Scott P Mainwaring. 2005. The third wave of democratization in Latin America: advances and setbacks. Cambridge University Press.

Herbst, Jeffrey. 2000. States and power in Africa: Comparative lessons in authority and control. Princeton University Press.

Jakiela, Pamela. 2021. "Simple Diagnostics for Two-Way Fixed Effects." arXiv preprint arXiv:2103.13229.

Khemani, Stuti. 2007. "Does delegation of fiscal policy to an independent agency make a difference? Evidence from intergovernmental transfers in India." Journal of Development Economics $82(2): 464-484$.

Korpi, Walter. 1983. The democratic class struggle. London: Routledge.

Korpi, Walter. 2006. "Power resources and employer-centered approaches in explanations of welfare states and varieties of capitalism: Protagonists, consenters, and antagonists." World politics 58(2):167-206.

Kriesi, Hanspeter, Edgar Grande, Romain Lachat, Martin Dolezal, Simon Bornschier and Timotheos Frey. 2008. West European politics in the age of globalization. Cambridge University Press Cambridge.

Lehoucq, Fabrice and David L Wall. 2004. "Explaining voter turnout rates in new democracies: Guatemala." Electoral Studies 23(3):485-500.

Litschig, Stephan. 2012. "Are rules-based government programs shielded from special-interest politics? Evidence from revenue-sharing transfers in Brazil." Journal of Public Economics 96(1112):1047-1060.

López-Calva, Luis Felipe and Nora Claudia Lustig. 2010. Declining inequality in Latin America: A decade of progress? Brookings Institution Press. 
Mejía, Daniel and Daniel Mauricio Rico Valencia. 2010. "La Microeconomía De La Producción y Tráfico De Cocaína En Colombia." Documento CEDE (2010-19).

Meltzer, Allan H and Scott F Richard. 1981. "A rational theory of the size of government." Journal of Political Economy 89(5):914-927.

Migdal, Joel S. 1988. Strong societies and weak states: state-society relations and state capabilities in the Third World. Princeton University Press.

Morgan, Jana and Nathan J Kelly. 2013. "Market inequality and redistribution in Latin America and the Caribbean." Journal of Politics 75(3):672-685.

Peceny, Mark and Michael Durnan. 2006. "The FARC's best friend: US antidrug policies and the deepening of Colombia's civil war in the 1990s." Latin American politics and society 48(2):95116.

Peñaranda Currie, Isabel, Silvia Otero-Bahamon and Simón Uribe. 2021. "What is the state made of? Coca, roads, and the materiality of state formation in the frontier." World Development 141:105395.

Philips, Andrew Q, Flávio DS Souza and Guy D Whitten. 2020. "Globalization and comparative compositional inequality." Political Science Research and Methods 8(3):509-525.

Pontusson, Jonas, David Rueda and Christopher R Way. 2002. "Comparative political economy of wage distribution: The role of partisanship and labour market institutions." British Journal of Political Science pp. 281-308.

Pop-Eleches, Grigore. 2008. From economic crisis to reform: IMF programs in Latin America and Eastern Europe. Princeton University Press.

Porto, Alberto and Pablo Sanguinetti. 2001. "Political determinants of intergovernmental grants: Evidence from Argentina." Economics 8 Politics 13(3):237-256.

Powell, G. B. 2000. Elections as instruments of democracy: Majoritarian and proportional visions. Yale University Press.

Roberts, Andrew and Byung-Yeon Kim. 2011. "Policy responsiveness in post-communist Europe: Public preferences and economic reforms." British Journal of Political Science pp. 819-839.

Rozo, Sandra V and Juan F Vargas. 2021. "Brothers or invaders? How crisis-driven migrants shape voting behavior." Journal of Development Economics 150:102636.

Rueda, David. 2007. "Left government, policy, and corporatism: Explaining the influence of partisanship on inequality." World Politics 60:349. 
Sader, Emir. 2011. The new mole: Paths of the Latin American left. Verso London.

Sanchez de la Sierra, Raul. 2020. "On the origins of the state: Stationary bandits and taxation in eastern congo." Journal of Political Economy 128(1):000-000.

Schady, Norbert R. 2000. "The political economy of expenditures by the Peruvian Social Fund (FONCODES), 1991-95." American political Science review 94(2):289-304.

Schmitt, Carina. 2016. "Panel data analysis and partisan variables: how periodization does influence partisan effects." Journal of European Public Policy 23(10):1442-1459.

Schmitt, Carina and Reimut Zohlnhöfer. 2019. "Partisan differences and the interventionist state in advanced democracies." Socio-Economic Review 17(4):969-992.

Scott, James C. 1998. Seeing like a state: How certain schemes to improve the human condition have failed. Yale University Press.

Solt, Frederick. 2016. "The standardized world income inequality database." Social science quarterly 97(5):1267-1281.

Stokes, Susan. 2001. Mandates and democracy: Neoliberalism by surprise in Latin America. Cambridge University Press.

Wiesehomeier, Nina and Kenneth Benoit. 2009. "Presidents, parties, and policy competition." Journal of Politics 71(4):1435-1447. 


\title{
Policy Responsiveness in Developing Democracies: Evidence from Latin America: Supplementary Information*
}

\author{
January 11, 2022
}

\section{Contents}

S1 Colombia ....................................2

S1.1 TWFE Diagnostics . . . . . . . . . . . . . . . . . . . . . 6

S1.2 Regression Tables . . . . . . . . . . . . . . . . . . . . . . . . 7

S1.2.1 Government Transfers . . . . . . . . . . . . . . . . . . . . 7

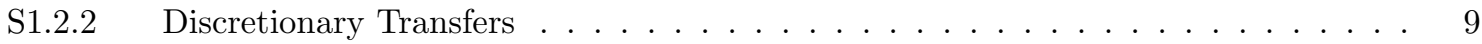

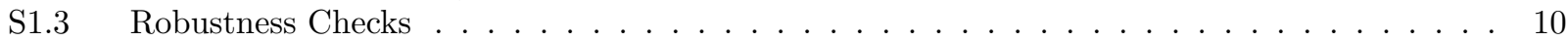

S1.3.1 Government Transfers . . . . . . . . . . . . . . . . . . . . 10

S1.3.2 Discretionary Transfers . . . . . . . . . . . . . . . . . . . . . . . . . . . . . . . . . . . . 13

S2 Cross-country Results . . . . . . . . . . . . . . . . . . . . . . 15

*All replication material, including R code and data, will be made available via Harvard University's Dataverse. 


\section{S1 Colombia}

\section{Data}

In this section, I present the summary statistics of the variables used in the regression analyses. In addition, I display plots with the distribution of logged government transfers per capita (figure S1), the evolution of the average government transfers per capita over time (figure S2), and the distribution of the logged CCT beneficiaries (figure S3). Likewise, I present the distribution of the electorate distance across elections (figure S4) and municipalities (figure S5), and the distribution of voter abstention (figure S6).

Although figure S1 suggests the presence of some outliers, my results are robust to the exclusion of municipalities with extreme values of government transfers (see table S9).

Table S1: Colombia - Summary Statistics

\begin{tabular}{lccc}
\hline \hline Statistic & $\mathrm{N}$ & Mean & St. Dev. \\
\hline Gov. Transfers Per Capita (millions) & 3,358 & $556,776.4$ & $682,920.4$ \\
Beneficiaries CCT & 2,130 & 46.2 & 110.7 \\
Electorate Distance & 3,355 & -0.3 & 0.8 \\
Population & 3,358 & $41,654.6$ & $254,755.0$ \\
Educ. Coverage & 3,291 & 85.5 & 18.0 \\
Educ. Enrollment & 3,358 & $6,966.9$ & $28,416.1$ \\
Unsatisfied Basic Needs & 3,358 & 48.2 & 21.3 \\
Unvacc. Population & 3,358 & $1,523.1$ & $8,244.8$ \\
Rurality Index & 3,358 & 0.6 & 0.2 \\
Ex-guerrilla & 2,236 & 1.7 & 7.0 \\
Displaced Pop. (Arrived) & 3,358 & 308.9 & $1,595.0$ \\
Income Growth Per Capita & 2,220 & 9.7 & 39.0 \\
Fiscal Performance Index & 3,281 & 65.2 & 8.4 \\
Homicides & 3,358 & 14.8 & 73.6 \\
Students & 3,348 & $8,402.4$ & $45,674.5$ \\
School Admin Staff & 2,791 & 156.6 & $1,156.4$ \\
Professors & 3,348 & 394.8 & $2,206.3$ \\
Abstention & 3,355 & 0.6 & 0.2 \\
Coca Crops & 3,358 & 0.2 & 0.4 \\
\hline
\end{tabular}




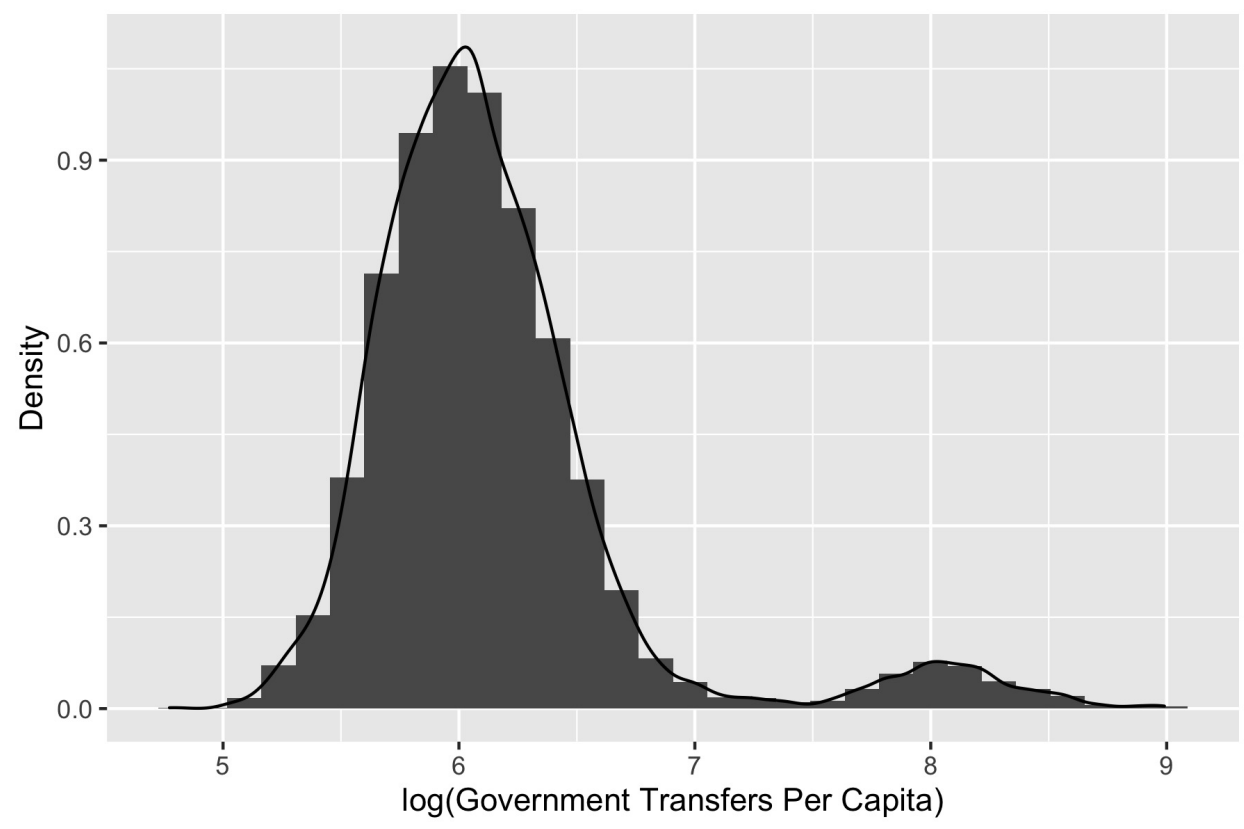

Figure S1: Distribution of log Government Transfers

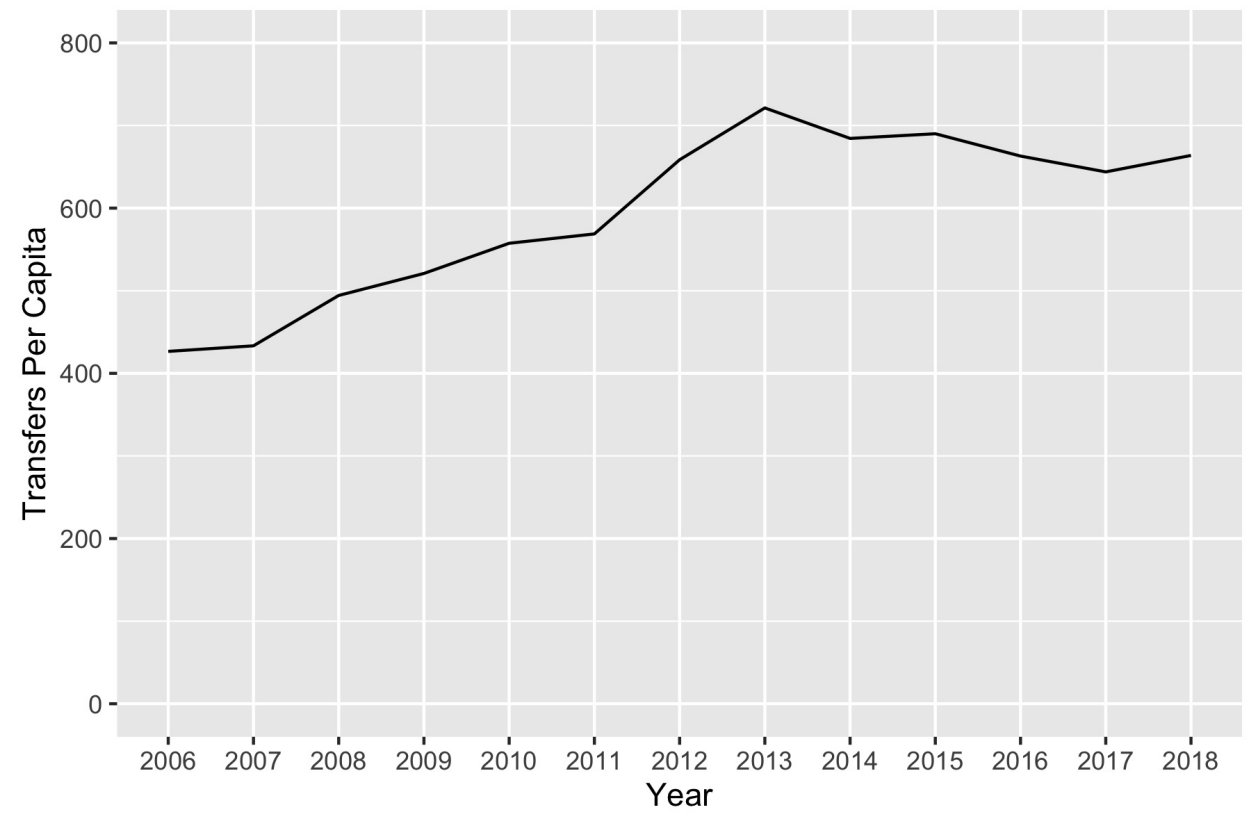

Figure S2: Evolution of Central Government Transfers

Note. Transfers to education and public health at constant 2015 COP. 


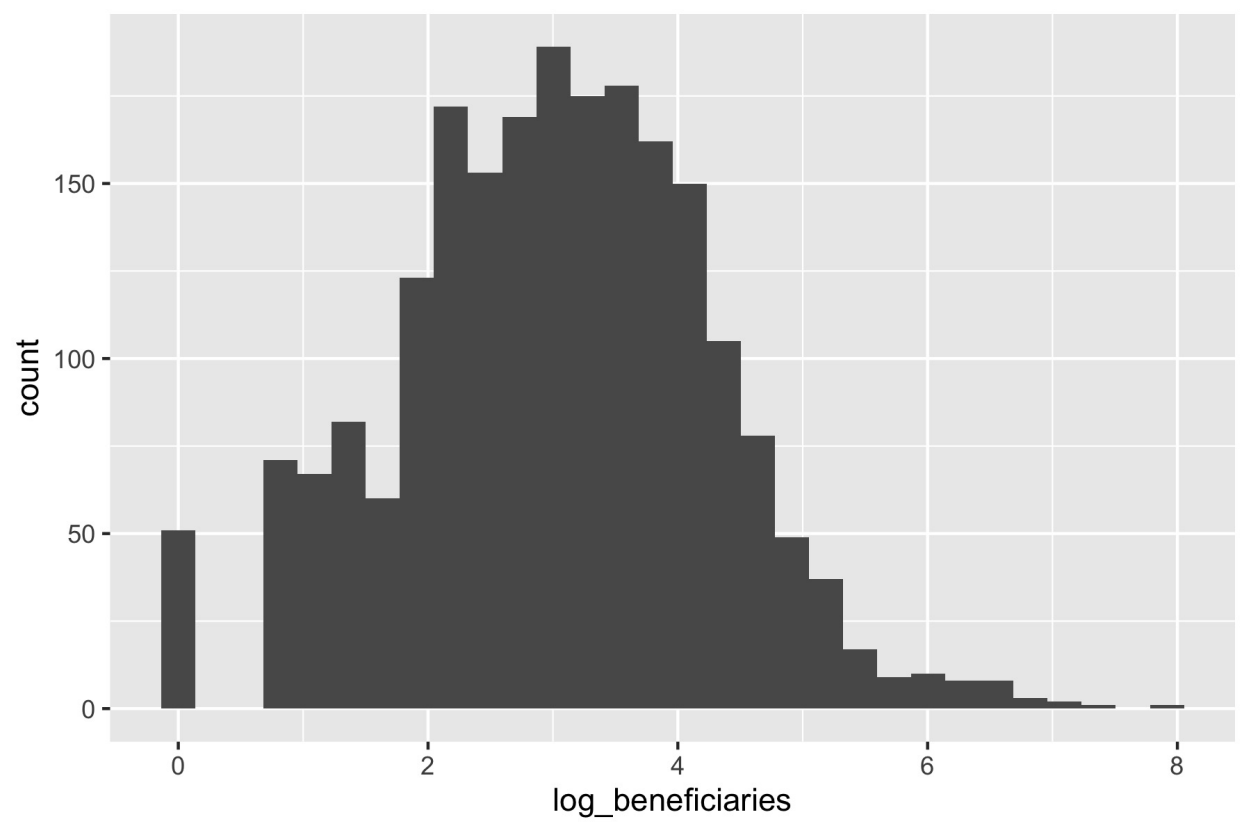

Figure S3: Distribution of $\log$ CCT beneficiaries
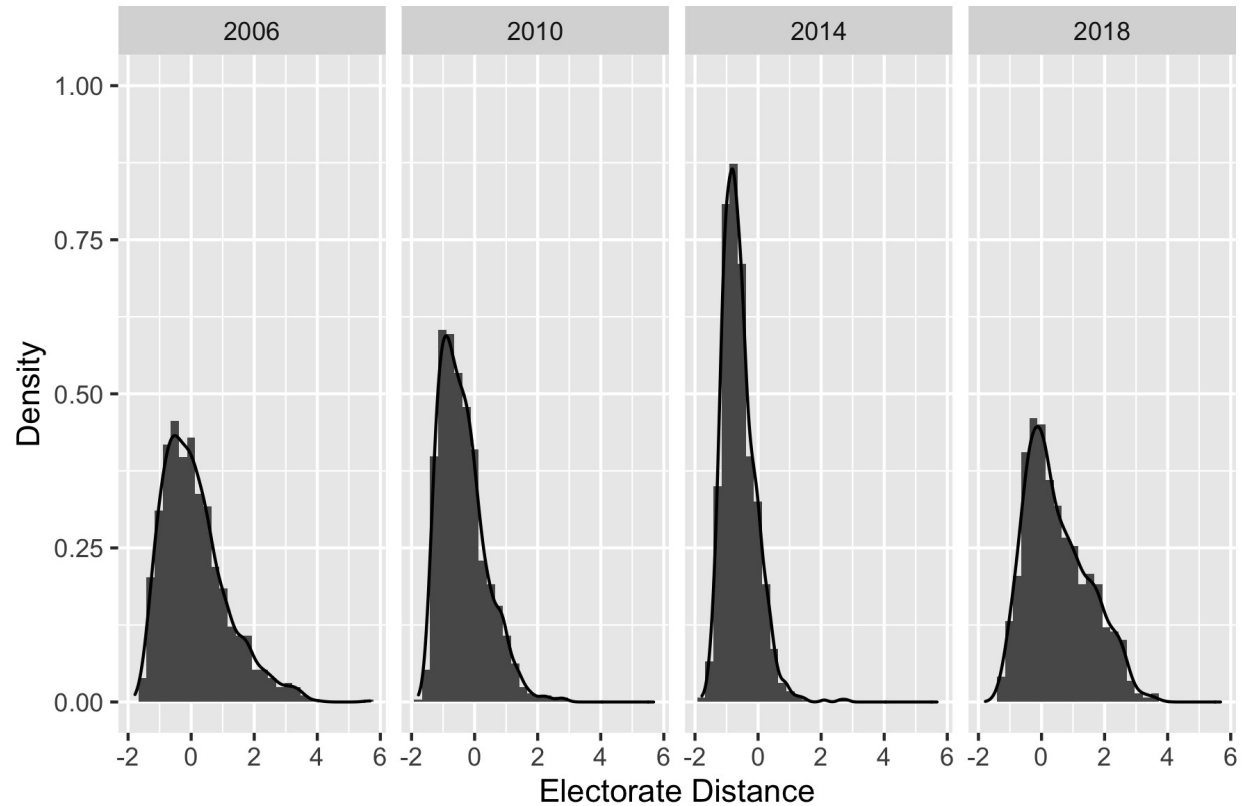

Figure S4: Distribution of Electorate Distance - Colombia

Note. Ideological distribution of the electorate in four national elections. Negative and positive values in the x-axis refer to left and right-wing ideology, respectively. 

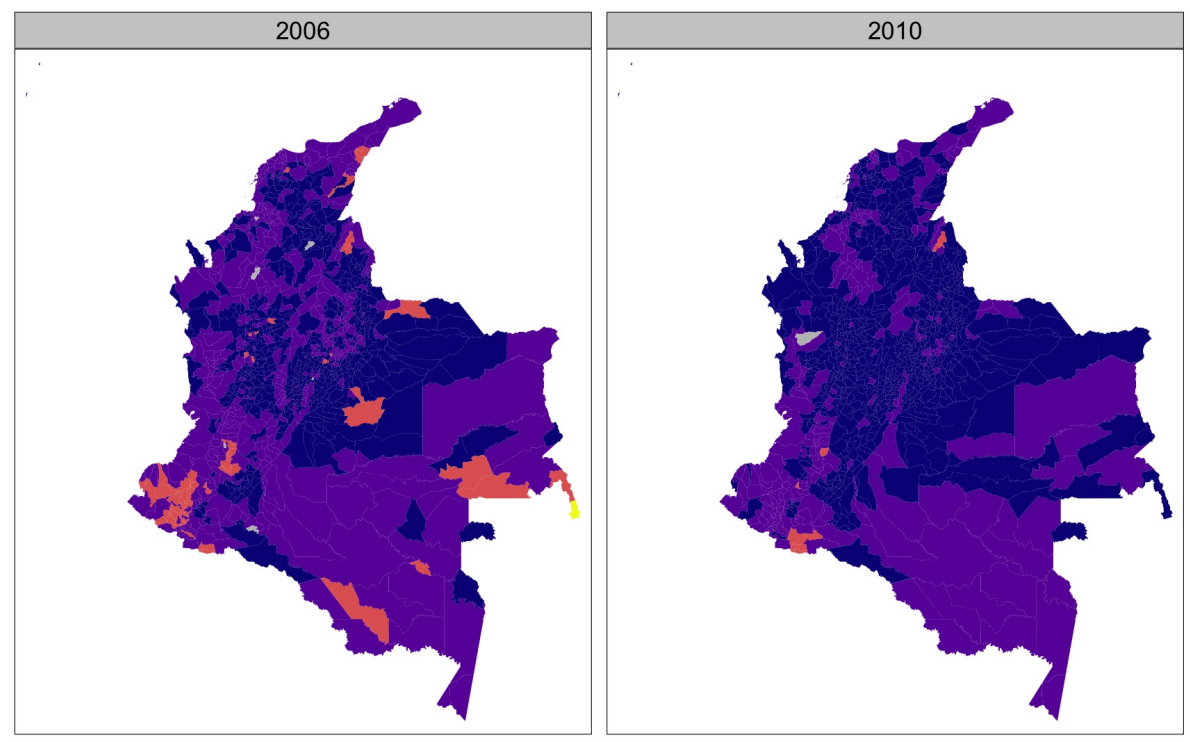

-2 to 0

0 to 2

2 to 4

4 to 6

Missing
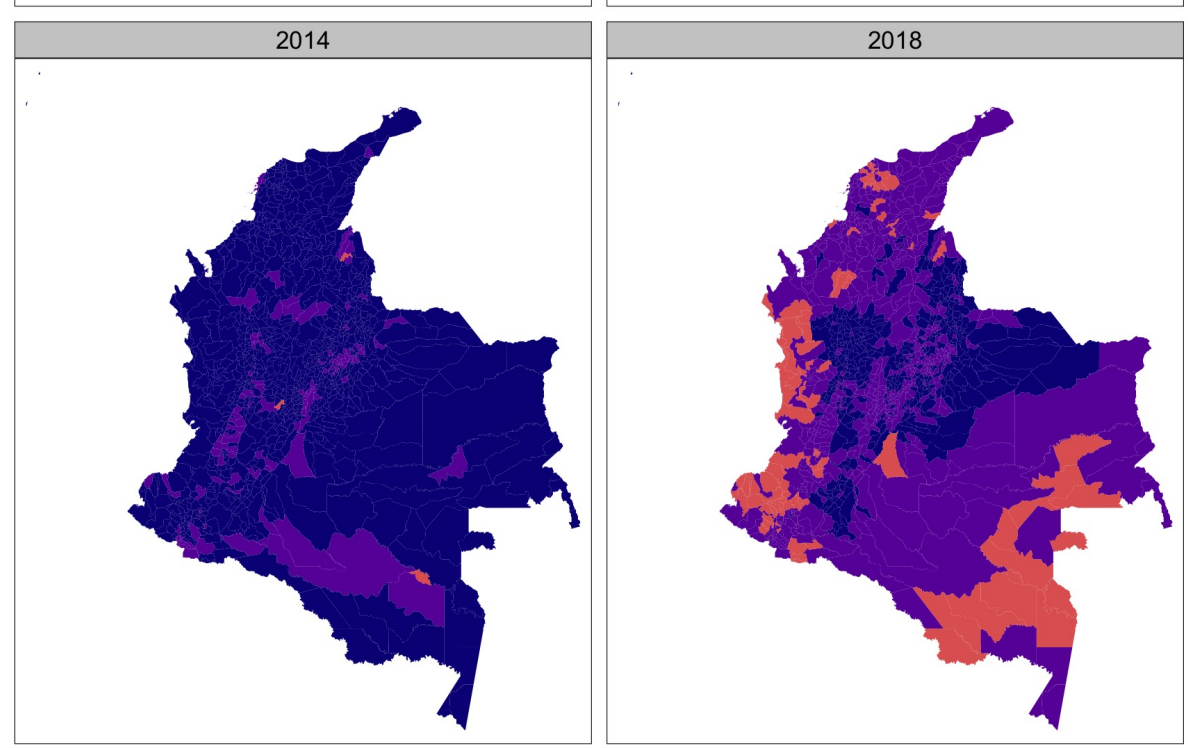

Figure S5: Municipal-level Variation of Electorate Distance - Colombia

Note. Cross-municipal variation of electorate distance in four national elections. Negative/positive values indicate municipalities located to the right/left of the government ideological position. 


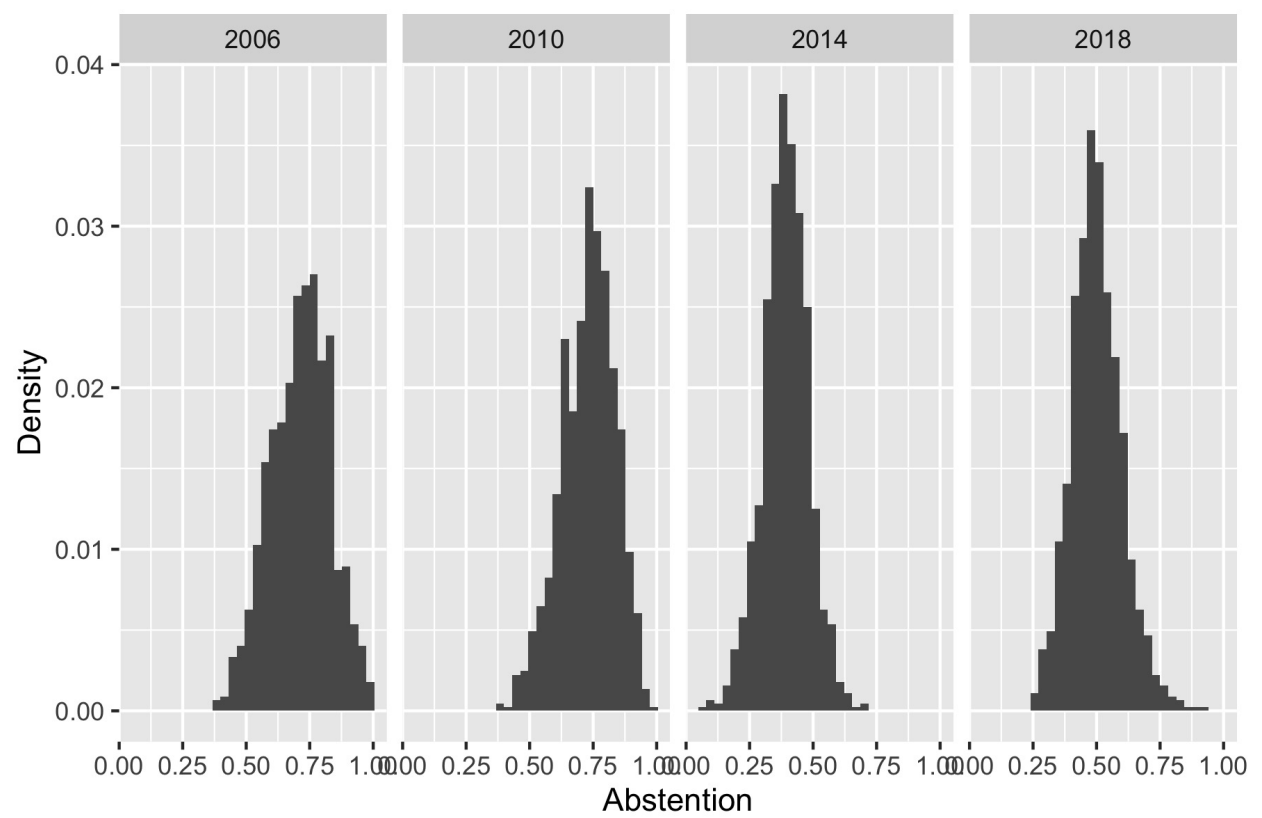

Figure S6: Distribution Abstention

\section{S1.1 TWFE Diagnostics}

In a recent paper, Jakiela (2021) suggests diagnostics tests for the feasibility of TWFE. Jakiela argues that an observable implication of the treatment effect homogeneity and common trends is a similar slope between treatment and control groups. I regress the residualized outcome variable (central government transfers) on the interaction between treatment group and residualized treatment (electorate distance). Because my treatment is a continuous variable, I classify those municipalities with a score above the mean of the electorate distance as treated units. Column 1 in table S2 shows that there is no significant difference between the slope of control and treatment groups. Column 2 provides further evidence of the homogeneity assumption. As expected, the interaction between the treatment variable and year yields null results. Importantly, the model reported in column 2 includes interacted controls. I conduct a similar diagnosis for discretionary transfers. Results are reported in table S3. As in government transfers, the homogeneity assumption holds.

Table S2: Government Transfers - Diagnostics for TWFE

\begin{tabular}{lcc}
\hline & 1 & 2 \\
\hline Treatment group X residualized treatment & -0.016 & \\
& $(0.014)$ & \\
Electorate distance X 2010 & -0.011 \\
& $(0.009)$ \\
Electorate distance X 2014 & 0.014 \\
& & $(0.014)$ \\
\hline Num. obs. & 3287 & 3287 \\
\hline${ }^{* * *} p<0.001 ;{ }^{* *} p<0.01 ;{ }^{*} p<0.05$ & &
\end{tabular}


Table S3: Discretionary Transfers - Diagnostics for TWFE

\begin{tabular}{lcc}
\hline & 1 & 2 \\
\hline Treatment group X residualized treatment & 0.029 & \\
& $(0.044)$ & \\
Electorate distance X 2010 & & 0.050 \\
& & $(0.069)$ \\
\hline Num. obs. & 1829 & 1829 \\
\hline${ }^{* * *} p<0.001 ;{ }^{* *} p<0.01 ;{ }^{*} p<0.05$ & &
\end{tabular}

\section{S1.2 Regression Tables}

\section{S1.2.1 Government Transfers}

Table S4: Electorate Distance Effect on Government Transfers Per Capita

\begin{tabular}{|c|c|c|c|}
\hline & 1 & 2 & 3 \\
\hline Electorate Distance & $\begin{array}{c}0.064^{* * *} \\
(0.010)\end{array}$ & $\begin{array}{c}0.027^{* * *} \\
(0.007)\end{array}$ & $\begin{array}{c}0.028^{* *} \\
(0.009)\end{array}$ \\
\hline Log Population & & $\begin{array}{c}0.178^{* * *} \\
(0.043)\end{array}$ & $\begin{array}{c}0.309^{* * *} \\
(0.090)\end{array}$ \\
\hline Educ. Coverage & & $\begin{array}{c}0.107^{* * *} \\
(0.012)\end{array}$ & $\begin{array}{c}0.109^{* * *} \\
(0.020)\end{array}$ \\
\hline Log Educ. Enrollment & & $\begin{array}{c}0.149^{* * *} \\
(0.038)\end{array}$ & $\begin{array}{l}0.135^{* *} \\
(0.041)\end{array}$ \\
\hline Unsatisfied Basic Needs & & $\begin{array}{c}0.117^{* * *} \\
(0.015)\end{array}$ & $\begin{array}{l}0.103^{* *} \\
(0.039)\end{array}$ \\
\hline Log Unvacc. Population & & $\begin{array}{c}-0.043^{* *} \\
(0.014)\end{array}$ & $\begin{array}{l}-0.038 \\
(0.021)\end{array}$ \\
\hline Rurality Index & & $\begin{array}{c}0.052 \\
(0.081)\end{array}$ & $\begin{array}{l}-0.100 \\
(0.128)\end{array}$ \\
\hline Log Ex-Guerrilla & & & $\begin{array}{l}-0.042 \\
(0.036)\end{array}$ \\
\hline Log Arrived Displaced Pop. & & & $\begin{array}{l}-0.009 \\
(0.006)\end{array}$ \\
\hline Inc. Growth Per Capita & & & $\begin{array}{l}-0.001 \\
(0.002)\end{array}$ \\
\hline Fiscal Performance Index & & & $\begin{array}{c}-0.042^{\text {*** }} \\
(0.013)\end{array}$ \\
\hline Log Homicides & & & $\begin{array}{c}0.006 \\
(0.007)\end{array}$ \\
\hline Log Students & & & $\begin{array}{l}-0.026 \\
(0.081)\end{array}$ \\
\hline Log School Admin Staff & & & $\begin{array}{c}0.002 \\
(0.012)\end{array}$ \\
\hline Log Professors & & & $\begin{array}{c}0.015 \\
(0.064) \\
\end{array}$ \\
\hline $\begin{array}{l}\text { Num. obs. } \\
\text { TWFE }\end{array}$ & $\begin{array}{l}4471 \\
\text { Yes }\end{array}$ & $\begin{array}{c}3287 \\
\text { Yes }\end{array}$ & $\begin{array}{c}2730 \\
\text { Yes }\end{array}$ \\
\hline
\end{tabular}
errors clustered at the municipal level 
Table S5: Marginal Effects of Electorate Distance on Government Transfers

\begin{tabular}{|c|c|c|c|}
\hline & 1 & 2 & 3 \\
\hline Electorate Distance & $\begin{array}{c}0.027^{*} \\
(0.011)\end{array}$ & $\begin{array}{c}-0.003 \\
(0.020)\end{array}$ & $\begin{array}{c}0.060^{*} \\
(0.028)\end{array}$ \\
\hline Abstention & $\begin{array}{l}0.332^{* *} \\
(0.104)\end{array}$ & $\begin{array}{c}0.044 \\
(0.101)\end{array}$ & $\begin{array}{c}0.304^{* * *} \\
(0.090)\end{array}$ \\
\hline Log Population & $\begin{array}{c}0.112^{* * *} \\
(0.026)\end{array}$ & $\begin{array}{c}0.116^{* * *} \\
(0.033)\end{array}$ & $\begin{array}{c}0.110^{* * *} \\
(0.020)\end{array}$ \\
\hline Educ. Coverage & $\begin{array}{l}0.152^{* *} \\
(0.051)\end{array}$ & $\begin{array}{c}0.055 \\
(0.069)\end{array}$ & $\begin{array}{c}0.135^{* * *} \\
(0.040)\end{array}$ \\
\hline Log Educ. Enrollment & $\begin{array}{c}0.064 \\
(0.053)\end{array}$ & $\begin{array}{c}0.219^{* * *} \\
(0.056)\end{array}$ & $\begin{array}{l}0.103^{* *} \\
(0.039)\end{array}$ \\
\hline Unsatisfied Basic Needs & $\begin{array}{l}-0.046 \\
(0.025)\end{array}$ & $\begin{array}{c}-0.009 \\
(0.040)\end{array}$ & $\begin{array}{c}-0.034 \\
(0.022)\end{array}$ \\
\hline Log Unvacc. Population & $\begin{array}{l}-0.171 \\
(0.161)\end{array}$ & $\begin{array}{c}0.097 \\
(0.139)\end{array}$ & $\begin{array}{c}-0.099 \\
(0.128)\end{array}$ \\
\hline Rurality Index & $\begin{array}{l}-0.018 \\
(0.045)\end{array}$ & $\begin{array}{c}-0.065 \\
(0.068)\end{array}$ & $\begin{array}{l}-0.041 \\
(0.036)\end{array}$ \\
\hline Log Ex-Guerrilla & $\begin{array}{l}-0.009 \\
(0.007)\end{array}$ & $\begin{array}{l}-0.012 \\
(0.019)\end{array}$ & $\begin{array}{l}-0.009 \\
(0.006)\end{array}$ \\
\hline Log Arrived Displaced Pop. & $\begin{array}{c}-0.000 \\
(0.003)\end{array}$ & $\begin{array}{l}-0.001 \\
(0.002)\end{array}$ & $\begin{array}{l}-0.001 \\
(0.002)\end{array}$ \\
\hline Inc. Growth Per Capita & $\begin{array}{c}-0.047^{* *} \\
(0.015)\end{array}$ & $\begin{array}{c}-0.039 \\
(0.028)\end{array}$ & $\begin{array}{c}-0.043^{* * *} \\
(0.013)\end{array}$ \\
\hline Fiscal Performance Index & $\begin{array}{c}0.004 \\
(0.007)\end{array}$ & $\begin{array}{c}0.011 \\
(0.016)\end{array}$ & $\begin{array}{c}0.006 \\
(0.007)\end{array}$ \\
\hline Log Homicides & $\begin{array}{c}-0.069 \\
(0.098)\end{array}$ & $\begin{array}{c}0.073 \\
(0.124)\end{array}$ & $\begin{array}{c}-0.029 \\
(0.082)\end{array}$ \\
\hline Log Students & $\begin{array}{l}-0.004 \\
(0.013)\end{array}$ & $\begin{array}{c}0.009 \\
(0.025)\end{array}$ & $\begin{array}{c}0.001 \\
(0.012)\end{array}$ \\
\hline Log School Admin Staff & $\begin{array}{c}0.098 \\
(0.059)\end{array}$ & $\begin{array}{c}-0.279 \\
(0.217)\end{array}$ & $\begin{array}{c}0.015 \\
(0.063)\end{array}$ \\
\hline Log Professors & & & $\begin{array}{c}0.018 \\
(0.056)\end{array}$ \\
\hline Electorate Distance X Abstention & & & $\begin{array}{c}-0.051 \\
(0.038)\end{array}$ \\
\hline Coca Crops & No & Yes & Yes \\
\hline TWFE & Yes & Yes & Yes \\
\hline Num. obs. & 2258 & 472 & 2730 \\
\hline
\end{tabular}




\section{S1.2.2 Discretionary Transfers}

Table S6: Electorate Distance Effect on log Beneficiaries CCT

\begin{tabular}{|c|c|c|c|}
\hline & 1 & 2 & 3 \\
\hline Electorate Distance & $\begin{array}{c}0.179^{* * *} \\
(0.031)\end{array}$ & $\begin{array}{c}0.207^{* * *} \\
(0.033)\end{array}$ & $\begin{array}{c}0.119^{* * *} \\
(0.024)\end{array}$ \\
\hline Log Population & & $\begin{array}{l}-0.834 \\
(1.325)\end{array}$ & $\begin{array}{c}-1.133^{* * *} \\
(0.156)\end{array}$ \\
\hline Inc. Growth Per Capita & & $\begin{array}{c}0.010 \\
(0.016)\end{array}$ & $\begin{array}{l}0.026^{*} \\
(0.012)\end{array}$ \\
\hline Log Arrived Displaced Pop. & & $\begin{array}{l}0.070^{*} \\
(0.028)\end{array}$ & $\begin{array}{c}0.091^{* * *} \\
(0.017)\end{array}$ \\
\hline Log Students - Primary & & $\begin{array}{l}-0.111 \\
(1.050)\end{array}$ & $\begin{array}{c}1.034^{* * *} \\
(0.148)\end{array}$ \\
\hline Log Schools & & $\begin{array}{c}0.487^{*} \\
(0.196)\end{array}$ & $\begin{array}{c}0.264^{* * *} \\
(0.046)\end{array}$ \\
\hline Log Students & & $\begin{array}{c}0.042 \\
(0.131)\end{array}$ & $\begin{array}{c}0.343^{* * *} \\
(0.059)\end{array}$ \\
\hline Log Health Centers & & $\begin{array}{l}-0.048 \\
(0.097)\end{array}$ & $\begin{array}{l}-0.042 \\
(0.033)\end{array}$ \\
\hline Log Sisben - Households & & $\begin{array}{c}-1.367^{* * *} \\
(0.406)\end{array}$ & $\begin{array}{l}0.151^{* *} \\
(0.058)\end{array}$ \\
\hline Log Displaced Pop. & & $\begin{array}{l}-0.017 \\
(0.037)\end{array}$ & $\begin{array}{l}0.058^{* *} \\
(0.020)\end{array}$ \\
\hline Log Threats & & $\begin{array}{c}0.116^{* * *} \\
(0.032)\end{array}$ & $\begin{array}{c}0.008 \\
(0.021)\end{array}$ \\
\hline Rurality Index & & $\begin{array}{c}0.861 \\
(0.773)\end{array}$ & $\begin{array}{c}-0.087^{* *} \\
(0.027)\end{array}$ \\
\hline Log Homicides & & $\begin{array}{c}0.051 \\
(0.043)\end{array}$ & $\begin{array}{l}-0.013 \\
(0.023)\end{array}$ \\
\hline Fiscal Performance Index & & $\begin{array}{c}0.087 \\
(0.047)\end{array}$ & $\begin{array}{l}0.051^{*} \\
(0.023)\end{array}$ \\
\hline Unsatisfied Basic Needs & & & $\begin{array}{c}0.081^{* * *} \\
(0.024) \\
\end{array}$ \\
\hline Year FE & Yes & Yes & Yes \\
\hline Municipality FE & Yes & Yes & No \\
\hline Num. obs. & 2130 & 1829 & 1829 \\
\hline
\end{tabular}

${ }^{* * *} p<0.001 ;{ }^{* *} p<0.01 ;{ }^{*} p<0.05$. Control variables in lagged values. Standard errors clustered at the municipal level 
Table S7: Marginal Effects of Electorate Distance on log Beneficiaries CCT

\begin{tabular}{|c|c|c|c|}
\hline & 1 & 2 & 3 \\
\hline Electorate Distance & $\begin{array}{c}0.306^{* * *} \\
(0.037)\end{array}$ & $\begin{array}{c}-0.033 \\
(0.070)\end{array}$ & $\begin{array}{c}0.510^{* * *} \\
(0.138)\end{array}$ \\
\hline Abstention & $\begin{array}{c}1.401 \\
(1.638)\end{array}$ & $\begin{array}{l}-3.081 \\
(2.675)\end{array}$ & $\begin{array}{c}-0.385 \\
(1.342)\end{array}$ \\
\hline Log Population & $\begin{array}{c}0.044^{* *} \\
(0.015)\end{array}$ & $\begin{array}{c}-0.139 \\
(0.142)\end{array}$ & $\begin{array}{c}0.011 \\
(0.017)\end{array}$ \\
\hline Inc. Growth Per Capita & $\begin{array}{c}0.059 \\
(0.033)\end{array}$ & $\begin{array}{c}0.033 \\
(0.075)\end{array}$ & $\begin{array}{l}0.075^{* *} \\
(0.028)\end{array}$ \\
\hline Log Arrived Displaced Pop. & $\begin{array}{l}-2.073 \\
(1.246)\end{array}$ & $\begin{array}{c}3.148 \\
(2.207)\end{array}$ & $\begin{array}{l}-0.460 \\
(1.061)\end{array}$ \\
\hline Log Students - Primary & $\begin{array}{c}0.341 \\
(0.175)\end{array}$ & $\begin{array}{l}2.091^{* *} \\
(0.755)\end{array}$ & $\begin{array}{l}0.406^{*} \\
(0.198)\end{array}$ \\
\hline Log Schools & $\begin{array}{l}-0.181 \\
(0.175)\end{array}$ & $\begin{array}{c}0.304 \\
(0.253)\end{array}$ & $\begin{array}{c}0.080 \\
(0.136)\end{array}$ \\
\hline Log Students & $\begin{array}{c}0.088 \\
(0.120)\end{array}$ & $\begin{array}{c}-0.125 \\
(0.110)\end{array}$ & $\begin{array}{c}-0.053 \\
(0.096)\end{array}$ \\
\hline Log Health Centers & $\begin{array}{c}-0.950^{*} \\
(0.419)\end{array}$ & $\begin{array}{c}-2.526^{* *} \\
(0.959)\end{array}$ & $\begin{array}{c}-1.217^{* *} \\
(0.411)\end{array}$ \\
\hline Log Sisben - Households & $\begin{array}{l}-0.026 \\
(0.040)\end{array}$ & $\begin{array}{c}0.134 \\
(0.128)\end{array}$ & $\begin{array}{l}-0.018 \\
(0.037)\end{array}$ \\
\hline Log Displaced Pop. & $\begin{array}{l}0.084^{*} \\
(0.039)\end{array}$ & $\begin{array}{c}0.082 \\
(0.067)\end{array}$ & $\begin{array}{c}0.122^{* * *} \\
(0.033)\end{array}$ \\
\hline Log Threats & $\begin{array}{l}-0.008 \\
(0.981)\end{array}$ & $\begin{array}{c}1.493 \\
(1.084)\end{array}$ & $\begin{array}{c}0.913 \\
(0.765)\end{array}$ \\
\hline Rurality Index & $\begin{array}{c}0.087 \\
(0.052)\end{array}$ & $\begin{array}{l}-0.057 \\
(0.081)\end{array}$ & $\begin{array}{c}0.040 \\
(0.044)\end{array}$ \\
\hline Log Homicides & $\begin{array}{c}0.106 \\
(0.055)\end{array}$ & $\begin{array}{c}0.054 \\
(0.088)\end{array}$ & $\begin{array}{c}0.088 \\
(0.046)\end{array}$ \\
\hline Fiscal Performance Index & & & $\begin{array}{c}0.466^{*} \\
(0.236)\end{array}$ \\
\hline Electorate Distance X Abstention & & & $\begin{array}{c}-0.668^{*} \\
(0.278)\end{array}$ \\
\hline Coca Crops & No & Yes & Yes \\
\hline TWFE & Yes & Yes & Yes \\
\hline Num. obs. & 1476 & 353 & 1829 \\
\hline
\end{tabular}

\section{S1.3 Robustness Checks}

\section{S1.3.1 Government Transfers}

Omitted variable bias is one of the main concerns in observational studies. To cause a confounding effect in my setting, omitted variables must vary over time and across municipalities. While I control for potential confounders with such characteristics, there might be variables that I did not consider or observe. To determine how serious the omitted variables should be to alter my results, I conduct a sensitivity analysis following Cinelli and Hazlett 2020. Table S8 shows the regression results reported in Figure ?? and additional information that details the sensitivity of the results to omitted confounding variables. The robustness value $\left(R V_{q=1}\right)$ of 6.72 percent means that hypothetical confounders as strong as the combination of the main institutional determinants of transfers (population and unsatisfied basic needs) would need to explain at least 6.72 percent of the residual variance of both electorate distance and transfers per capita at $t+1$ to wash out the observed effect. In addition, the robustness value for testing the null hypothesis $\left(R V_{q=1, \alpha=0.05}\right)$ is 2 percent. This means that unobserved confounders that do not explain at least 2 percent of the residual variance in both electorate distance and transfers per capita are not sufficiently strong 
for the estimate to lose statistical significance at the 0.05 level. The values of $R_{Y \quad Z \mid X, D}^{2}=3.4$ percent and $R_{D Z \mid X}^{2}=$ 0.1 percent provide bounds on confoundings as strong as the combination of the main institutional determinants of transfers. Because both values are below $R V_{q=1}$, confounders as strong as the institutional determinants are not sufficient to wipe out the observed estimate.

Table S8: Sensitivity Analysis

Outcome: Log Government Transfers Per Capita

\begin{tabular}{lrrrrrr}
\hline \hline Treatment: & Est. & S.E. & t-value & $R_{Y \sim D \mid \mathbf{X}}^{2}$ & $R V_{q=1}$ & $R V_{q=1, \alpha=0.05}$ \\
\hline Electorate Distance & 0.028 & 0.01 & 2.798 & $0.5 \%$ & $6.7 \%$ & $2.1 \%$ \\
\hline $\mathrm{df}=1616$ & \multicolumn{5}{c}{ Bound (1x Inst. Drivers): } & $R_{Y \sim Z \mid \mathbf{X}, D}^{2}=3.4 \%, R_{D \sim Z \mid \mathbf{x}}^{2}=0.1 \%$
\end{tabular}

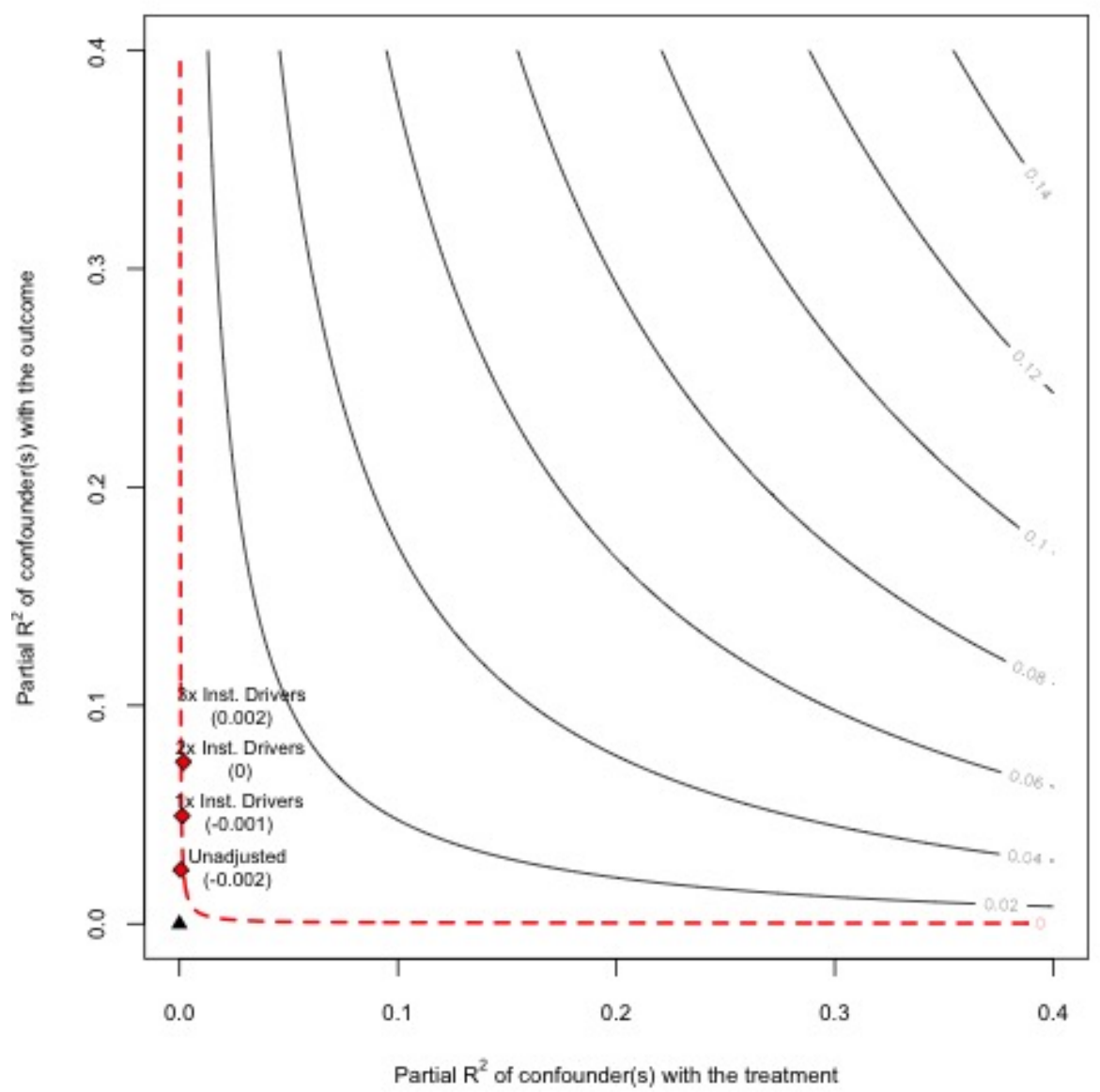

Figure S7: Effect Estimates at Different Levels of Assumed Confounding.

Table S9 presents results after removing municipalities with extreme reported values in government transfers per capita. The effect of the electorate distance holds. 
Table S9: Electorate Distance Effect on Government Transfers Per Capita

\begin{tabular}{lc}
\hline & 1 \\
\hline Electorate Distance & $0.027^{* * *}$ \\
& $(0.008)$ \\
Log Population & 0.122 \\
& $(0.064)$ \\
Educ. Coverage & $0.103^{* * *}$ \\
& $(0.016)$ \\
Log Educ. Enrollment & $0.065^{*}$ \\
& $(0.029)$ \\
Unsatisfied Basic Needs & $0.110^{* * *}$ \\
& $(0.024)$ \\
Log Unvacc. Population & $-0.036^{*}$ \\
& $(0.018)$ \\
Rurality Index & 0.013 \\
& $(0.101)$ \\
Log Ex-Guerrilla & 0.000 \\
& $(0.018)$ \\
Log Arrived Displaced Pop. & -0.006 \\
& $(0.005)$ \\
Inc. Growth Per Capita & 0.001 \\
& $(0.001)$ \\
Fiscal Performance Index & $-0.020^{*}$ \\
& $(0.008)$ \\
Log Homicides & -0.000 \\
& $(0.006)$ \\
Log Students & -0.112 \\
& $(0.060)$ \\
Log School Admin Staff & 0.010 \\
& $(0.008)$ \\
Log Professors & 0.057 \\
& $(0.043)$ \\
\hline Num. obs. & 2632 \\
TWFE & Yes \\
\hline$* * * p<0.001 ; * * p<0.01 ;{ }^{*} p<0.05$. Control \\
variables in lagged values. Standard errors clustered \\
at the municipal level
\end{tabular}

As mentioned in the discussion section, the inclusion of the 2018 elections in the analysis wipes out the effect of the electorate distance on central government transfers. Table S10 suggests that the null effect is driven by 2018. Column 1 presents the null result of electorate distance on government transfers. However, column 2 shows that the effect of electorate distance is negative and significant in 2018. 
Table S10: Electorate Distance Effect on Government Transfers Per Capita

\begin{tabular}{lcc}
\hline & 1 & 2 \\
\hline Electorate distance & -0.003 & 0.013 \\
& $(0.004)$ & $(0.007)$ \\
Electorate distance X 2010 & & -0.013 \\
& & $(0.009)$ \\
Electorate distance X 2014 & & 0.003 \\
& & $(0.011)$ \\
Electorate distance X 2018 & & $-0.034^{* * *}$ \\
& & $(0.009)$ \\
\hline Num. obs. & 4384 & 4384 \\
TWFE & Yes & Yes \\
\hline
\end{tabular}

${ }^{* * *} p<0.001 ;{ }^{* *} p<0.01 ;{ }^{*} p<0.05$. Control variables in lagged values. Control variables in column 2 are interacted with year.

Standard errors clustered at the municipal level

\section{S1.3.2 Discretionary Transfers}

Table S11 and figure S8 show the results of the sensitivity analysis for the logged CCT beneficiaries. In this analysis, I use logged displaced population that arrives at a municipality and logged households registered in the System of Identification of Social Program Beneficiaries (SISBEN) as the benchmark covariate. The CCT program targets both of these groups (DPS, 2019). In this case, the robustness value $\left(R V_{q=1}\right)$ is 21.3 and the robustness value for testing the null hypothesis $\left(R V_{q=1, \alpha=0.05}\right)$ is 15.9 percent. The latter means that unobserved confounders that do not explain at least 15.9 percent of the residual variance in electorate distance and logged CCT beneficiaries are not sufficiently strong for the estimate to lose statistical significance at the 0.05 level.

Table S11: Sensitivity Analysis - CCT beneficiaries Outcome: Log CCT beneficiaries

\begin{tabular}{|c|c|c|c|c|c|c|}
\hline Treatment: & Est. & S.E. & t-value & $\overline{R_{Y \sim D \mid \mathbf{X}}^{2}}$ & $R V_{q=1}$ & $\bar{R} R V_{q=1, \alpha=0.05}$ \\
\hline Electorate Distance & 0.207 & 0.029 & 7.107 & $5.4 \%$ & $21.3 \%$ & $15.9 \%$ \\
\hline
\end{tabular}




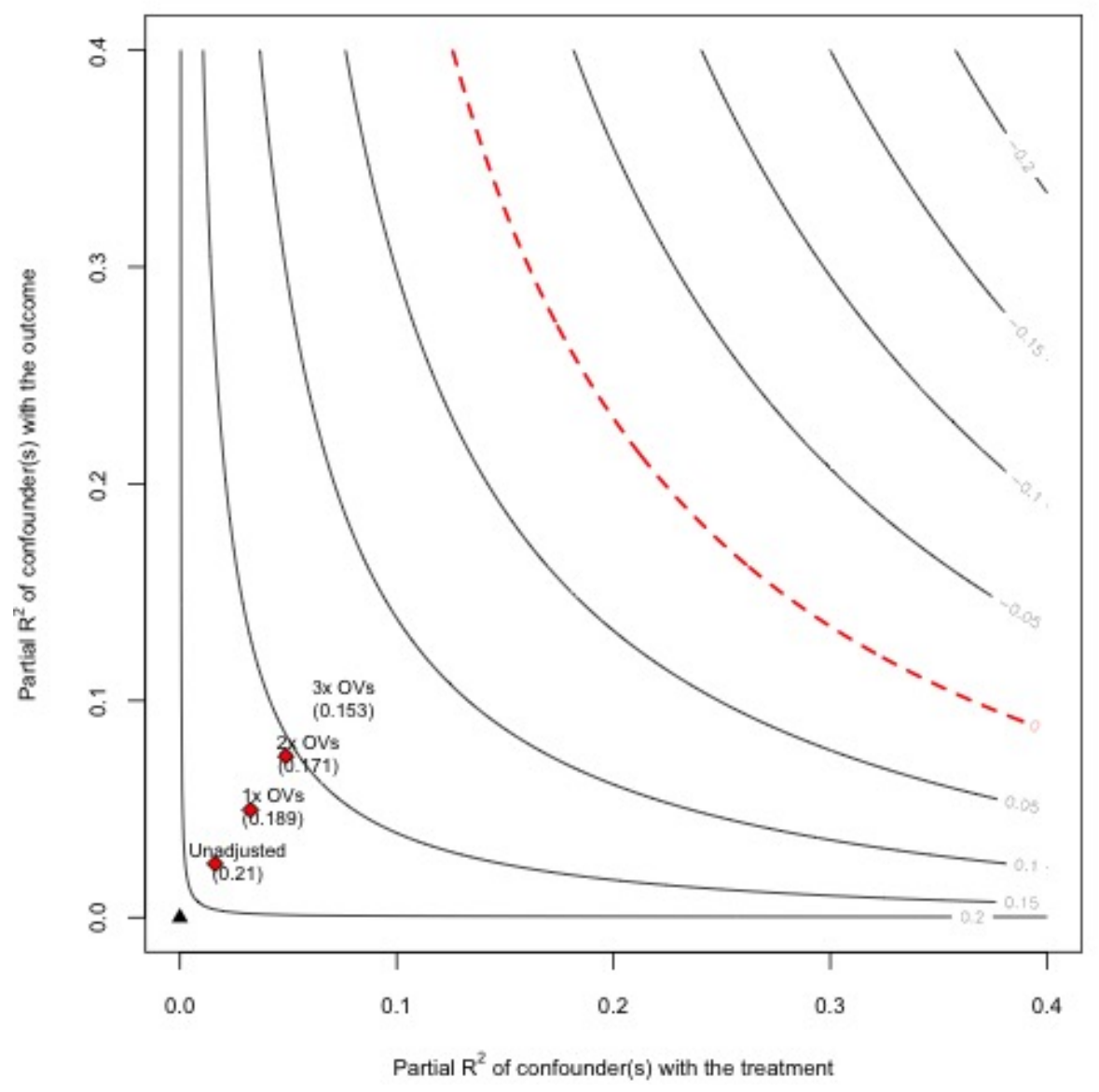

Figure S8: Effect Estimates at Different Levels of Assumed Confounding. 


\section{S2 Cross-country Results}

List of countries: Argentina, Bolivia, Brazil, Chile, Colombia, Costa Rica, Dominican Republic, Ecuador, El Salvador, Guatemala, Honduras, Mexico, Nicaragua, Panama, Paraguay, Peru, Uruguay, Venezuela.

Table S12: Country-level Panel - Summary Statistics

\begin{tabular}{lccc}
\hline \hline Statistic & N & Mean & St. Dev. \\
\hline Average Redistribution & 92 & 0.03 & 0.03 \\
Electorate Distance & 97 & -0.04 & 1.0 \\
President Ideology & 97 & 11.4 & 5.3 \\
Log GDP Per Capita & 97 & 8.5 & 0.7 \\
Proportion Elderly & 97 & 10.2 & 3.4 \\
Gini Market & 97 & 0.5 & 0.04 \\
Legal Opposition & 97 & 1.1 & 1.3 \\
Inflation & 97 & 231.8 & $1,489.5$ \\
Unemployment & 97 & 7.1 & 3.5 \\
Education & 97 & 2.1 & 0.7 \\
Terms of Trade & 97 & 131.3 & 62.1 \\
Trade Openness & 97 & 62.1 & 27.4 \\
Economic Growth & 97 & 3.9 & 3.2 \\
External Debt & 97 & 44.2 & 32.4 \\
\hline
\end{tabular}


Table S13: Electorate Distance Effect on Average Redistribution. Country-level Panel

\begin{tabular}{|c|c|c|}
\hline & 1 & 2 \\
\hline Electorate Distance & $\begin{array}{c}0.014^{*} \\
(0.005)\end{array}$ & $\begin{array}{c}0.010^{*} \\
(0.004)\end{array}$ \\
\hline President Ideology & $\begin{array}{c}-0.017^{*} \\
(0.006)\end{array}$ & $\begin{array}{c}-0.002^{*} \\
(0.001)\end{array}$ \\
\hline Log GDP Per Capita (lag) & $\begin{array}{c}-0.036 \\
(0.024)\end{array}$ & $\begin{array}{l}-0.018 \\
(0.027)\end{array}$ \\
\hline Proportion Elderly (lag) & $\begin{array}{c}0.008^{*} \\
(0.004)\end{array}$ & $\begin{array}{c}0.010^{*} \\
(0.004)\end{array}$ \\
\hline Gini Market (lag) & $\begin{array}{c}0.128 \\
(0.118)\end{array}$ & $\begin{array}{c}0.098 \\
(0.146)\end{array}$ \\
\hline Legal Opposition & $\begin{array}{c}0.001 \\
(0.003)\end{array}$ & $\begin{array}{l}-0.001 \\
(0.002)\end{array}$ \\
\hline Inflation (lag) & $\begin{array}{l}-0.000 \\
(0.000)\end{array}$ & $\begin{array}{c}0.000 \\
(0.000)\end{array}$ \\
\hline Unemployment (lag) & $\begin{array}{l}-0.001 \\
(0.001)\end{array}$ & $\begin{array}{l}-0.001 \\
(0.001)\end{array}$ \\
\hline Education (lag) & $\begin{array}{l}-0.007 \\
(0.010)\end{array}$ & $\begin{array}{l}-0.002 \\
(0.009)\end{array}$ \\
\hline Terms of Trade (lag) & $\begin{array}{c}0.000 \\
(0.000)\end{array}$ & $\begin{array}{l}-0.000 \\
(0.000)\end{array}$ \\
\hline Trade Openness (lag) & $\begin{array}{c}0.000 \\
(0.000)\end{array}$ & $\begin{array}{c}0.000 \\
(0.000)\end{array}$ \\
\hline Economic Growth (lag) & $\begin{array}{l}-0.001 \\
(0.000)\end{array}$ & $\begin{array}{l}-0.000 \\
(0.000)\end{array}$ \\
\hline External Debt (lag) & $\begin{array}{l}-0.000 \\
(0.000)\end{array}$ & $\begin{array}{l}-0.000 \\
(0.000)\end{array}$ \\
\hline Country FE & Yes & Yes \\
\hline Year FE & Yes & No \\
\hline Num. Obs. & 92 & 435 \\
\hline
\end{tabular}

\section{References}

Cinelli, Carlos and Chad Hazlett. 2020. "Making sense of sensitivity: Extending omitted variable bias." Journal of the Royal Statistical Society: Series B (Statistical Methodology) 82(1):39-67.

DPS. 2019. Manual Operativo. Familias en Acción. Technical report Departamento para la Prosperidad Social. Jakiela, Pamela. 2021. "Simple Diagnostics for Two-Way Fixed Effects." arXiv preprint arXiv:2103.13229 . 